\title{
Assessing and Prioritizing the Climate Change Policy Objectives for Sustainable Development in Pakistan
}

\author{
Waqas Ahmed ${ }^{1,2}{ }^{-}$, Qingmei Tan ${ }^{1}$, Ghulam Muhammad Shaikh ${ }^{3}{ }^{\circledR}$, Hamid Waqas ${ }^{2}$, \\ Nadeem Ahmed Kanasro ${ }^{4}$, Sharafat Ali 1,5,6,7 ${ }^{\mathbb{D}}$ and Yasir Ahmed Solangi ${ }^{8, * \mathbb{D}}$ \\ 1 College of Economics and Management, Nanjing University of Aeronautics and Astronautics, \\ Nanjing 211106, China; waqas19@nuaa.edu.cn or wahmed@wiut.uz (W.A.); tanchina@nuaa.edu.cn (Q.T.); \\ sharafat.ali@nuaa.edu.cn (S.A.) \\ 2 School of Business and Economics, Westminster International University in Tashkent, \\ Tashkent 100047, Uzbekistan; hwaqas@wiut.uz \\ 3 Department of Computer Science, Bahria University, Karachi 75260, Pakistan; \\ ghulammuhammad.bukc@bahria.edu.pk \\ 4 Department of Computer Science, Sindh University Campus, Larkana 77230, Pakistan; \\ nadeem.kanasro@usindh.edu.pk \\ 5 Higher Education Department (HED), Government of the Punjab, Lahore 54000, Punjab, Pakistan \\ 6 Department of Economics, Government Postgraduate College Kot Sultan, Kot Sultan, \\ Layyah 31650, Punjab, Pakistan \\ 7 Bahauddin Zakariya University Multan, Layyah Campus, Layyah 31200, Punjab, Pakistan \\ 8 School of Economics and Management, Nanjing University of Science and Technology, \\ Nanjing 210094, China \\ * Correspondence: yasir.solangi86@hotmail.com or yasir.solangi@nuaa.edu.cn
}

Received: 28 June 2020; Accepted: 20 July 2020; Published: 22 July 2020

check for updates

\begin{abstract}
The world is facing the observable and direct impacts of climate change in the shape of extreme weather events, irregular precipitation, glacial melt, sea-level rise, an asymmetric average temperature trends, higher oceanic temperatures, damage to natural ecosystems, and biodiversity. In 2015, collective wisdom stirred the global community to agree upon two unprecedented milestones in recent human history-the Paris agreement and sustainable development goals (SDGs). The twin global agreements set a platform for collective efforts to secure socio-economic and climatic sustainability. Pakistan also joined the board to put forth policy interventions for the mitigation and adaption of climate change risks to maintain symmetry between the environmental quality and economic development. The government of Pakistan (GOP) formulated the National Climate Change Policy (NCCP (2012)) and passed the Pakistan Climate Change Act (PCCA (2017)) to provide an impetus for the implementation of the NCCP. Yet, an appropriate assessment and prioritization of the objectives of the NCCP are indispensable for productive and effective policies to achieve the targets. This study serves this purpose by prioritizing the climate change policy objectives (CCPOs) based on symmetric principles, i.e., energy, transport, urban and town planning, industry, and agriculture as criteria, with 17 sub-criteria in total. The fuzzy analytical hierarchy process (AHP) results show that the energy sector is the most pivotal while implementing the NCCP. Energy production is the most critical area that needs mitigation policy intervention for shifting the energy mix of the economy from high-carbon to low-carbon energy. The fuzzy AHP analysis further revealed the railway, population and urbanization, air pollution, crop growing practices and techniques as the most important related to transport, urban planning, industry, and agriculture sub-criteria, respectively. The fuzzy VIseKriterijumska Optimizacija I Kompromisno Resenje (VIKOR) analysis showed the ranking of the CCPOs from high to low through the integration of policies, institutional capacity building, water security, natural resource management, natural disaster management, environmental financial structure development, and social sector development. The findings of the present research
\end{abstract}


would be helpful for experts and policymakers to re-examine the NCCP and put forth action plans to achieve sustainable climate and SDGs.

Keywords: climate change policy; mitigation; adaptation; sustainability; development; water management; sustainable development goals; decision criteria; fuzzy AHP-VIKOR

\section{Introduction}

The global community realized the severity of climate change, and global warming stressed the need to address this immediately. Both global agreements are co-dependent and mutually reinforcing as climate change poses risks to economic development, whereas transitions to produce low-carbon emissions heavily depend on social, economic, and environmental development [1,2]. There has been a heated debate amongst policymakers whether responding to climate change undermines economic growth. However, Tobin [3], tracking opposing economic ideas across the environmental debate, proclaims that climate change is an opportunity despite the arguments of many experts that economic growth and climate actions are conflicting. Sustainable Development Goal (SDG) 13 refers to urgent action to combat climate change and its impacts. Moreover, SDG 14 (life below water) and 15 (life on land) also assert the importance of nature for survival. Similarly, the Paris agreement (2015) [4] aims to strengthen the global response to the threats posed by climate change. It also aims to strengthen the capability and ability of national economies to deal with climate change through a new technology framework, enhanced capacity building framework, and appropriate financial flows.

The objectives set in the global climate agreement and the 2030 agenda for SGDs could be achieved through a comprehensive climate change policy (CCP) and its strict implementation [4]. However, the promulgation and design of a CCP, and its effective and productive implementation, is a huge challenge especially for developing countries like Pakistan characterized by low growth trajectories, high levels of poverty, and a vulnerability to climate change. Pakistan is also amongst the countries on board to fulfill the ambitious plans of mitigation and adaptation to keep the global temperature rise "well below" $2{ }^{\circ} \mathrm{C}[5]$. Climate change-induced erratic weather patterns have emerged as the biggest environmental challenge affecting every sector of the economy, particularly energy, water resources, health, and biodiversity, with adverse impacts on agricultural productivity [6]. Pakistan is prone to climate change-induced extreme weather and disasters. Chronic poverty and frequent disasters, coupled with political and economic volatility, have driven undernutrition in and food security from the economy [7]. Over the last few years, Pakistan has been continuously ranked among the most affected countries by climate change both in the long-term Global Climate Risk Index (GCRI) and the GCRI for the respective year. Pakistan ranked fifth in the 10 most vulnerable economies to climate change in the last two decades, with an average Climate Risk Index (CRI) score of 28.83 between 1998-2019 [8]. Regarding water resources, Pakistan is on the verge of a water crisis as it is moving fast from a water "stressed" to water "scarce" economy as annual per capita water availability has fallen below 1000 cubic meters [9].

Being an agro-based economy and a negligible contributor to climate change, the fifth largest country in the world is at the forefront of the climate change-induced hazards which are major challenges to its food security. However, the international and national focus is needed to mitigate and adapt climate change-induced risks [10]. Realizing the devastations of climate change and the damages caused by it, the government of Pakistan (GOP) introduced the National Environmental Policy (NEP) in 2015 [11]. Following the global trend, Pakistan responded to climate change and initiated a climate change policy and actions. Pakistan was amongst the leading countries introducing the National Climate Change Policy (NCCP) in 2012 [12]. The formation of the NCCP was a positive development to mitigate and adapt climate change-induced risks in the country. The NCCP was a multi-sector policy stressing the mitigation and adaptation measures with regard to energy production, 
transport, urban development, human health, forestry, and disaster preparedness. In addition to this, it also emphasized technology transfer, institutional capacity building, strengthening, and increasing public awareness regarding climate change coupled with envisioned intra-national, inter-provincial, inter-ministerial, regional, and international cooperation. In 2017, the GOP passed the Pakistan Climate Change Act (PCCA) to "fast-track measures needed to implement actions on the ground" [13]. However, the implementation of the NCCP has been a great challenge in Pakistan. It is imperative to assess and prioritize the NCCP's objectives considering the multiple-faceted socio-economic, political, institutional, administrative, and technical aspects for the successful implementation of the NCCP to ensure the achievement of SDGs.

This study is a major contribution in terms of the prioritization of climate change policy objectives based on a multi-criteria decision analysis (MCDA). The study prioritizes the NCCP objectives set by the government of Pakistan (GOP) considering the energy sector, transport, urban planning, and town planning, industry and agriculture as the climate change policy objective criteria (CCPOC), and energy production, transmission and distribution of electricity, fiscal reforms in the energy sector, road infrastructure, general transport, railways, population and urbanization, integrated mass-transit systems, solid waste management, water management, air pollution, water pollution, land pollution/brownfield, crop growing practices, livestock, and forestry as climate change policy objective sub-criteria (CCPOSC). One of the most widely used MCDA tools, the fuzzy analytical hierarchy process (AHP), has been used to obtain the ranking of each CCPOC with respect to the goal, ranking of each CCPOSC with respect to their respective CCPOC, and the overall prioritization of the CCPOSC with respect to the goal. Further, a fuzzy VIKOR has been used to rank the Climate Change Policy Objective Alternatives (CCPOAs) for a deeper insight into the NCCP for its efficient and productive implementation ensuring sustainable development in Pakistan.

\section{Climate Change Policy Objectives with Special Reference to Pakistan's Economy}

Since the GOP has formulated the NCCP [12] and passed the PCCA [13], the implementation of the NCCP has been one of the great challenges that the Pakistan economy is posed with. The major objectives set in the NCCP include institutional capacity building, water management, security, the integration of national policies, natural resource management, natural disaster nanomagnet social sector development, and environmental financial structure development [12]. The strength of any effective and optimal policy lies in doable goals/objectives backed by resources to put the policy in motion [14]. The prioritization of climate change policy objectives is of prime importance for its systematic and successful implantation. This study serves this purpose for a deeper and profound understanding of the climate change policy and its objectives to ensure climate sustainability. The following subsections represent a detailed introduction to the climate change policy objective criteria, climate change policy objective sub-criteria, and climate change policy objectives (alternatives).

\subsection{Climate Change Policy Objective Criteria (CCPOC) and Climate Change Policy Objective Sub-Criteria (CCPOSC) Policy in Pakistan}

Based on the literature review of various major studies regarding drivers of climate change and sources that cause climate change, the authors identified energy [15-18], transport [19-21], urban and town planning and development [22-25], industry [26-29], and agriculture [30-32] as the most relevant sectors. Similarly, based on the previous important studies, the climate change policy objective sub-criteria are also identified and listed below in Table 1. 
Table 1. Climate change policy objective criteria (CCPOC (criteria)) and climate change policy objective sub-criteria (CCPOSC (sub-criteria)).

\begin{tabular}{|c|c|c|}
\hline Criteria & Sub-Criteria & Description \\
\hline \multirow{3}{*}{ Energy (CСPOC1) } & $\begin{array}{l}\text { Energy } \\
\text { Production } \\
\text { (CCPOSC11) }\end{array}$ & $\begin{array}{l}\text { Energy production is one of the foremost reasons for } \\
\text { anthropogenic } \mathrm{CO}_{2} \text { emissions [15-17] Mitigation and } \\
\text { adaptation measures are required on an urgent basis for } \\
\text { environmental resilience. }\end{array}$ \\
\hline & $\begin{array}{l}\text { Transmission and Distribution } \\
\text { (CCPOSC12) }\end{array}$ & $\begin{array}{l}\text { Upgradation and improvement of transmission lines and } \\
\text { distribution systems could help reduce line losses and } \\
\text { increase the efficient use of produced energy [18]. }\end{array}$ \\
\hline & $\begin{array}{c}\text { Fiscal Reforms } \\
\text { in the Energy Sector (CCPOSC13) }\end{array}$ & $\begin{array}{l}\text { Fiscal reforms in energy sectors are direly needed to tackle } \\
\text { circular debt [33]. Energy investment policy needs to be } \\
\text { focussed on investment in green energy. A shift of energy } \\
\text { mix from non-renewable to renewable energy sources to } \\
\text { ensure environmental sustainability. }\end{array}$ \\
\hline \multirow{3}{*}{ Transport (CСPOC2) } & Road Infrastructure (CCPOSC21) & $\begin{array}{l}\text { Road infrastructure is vital for the movement of people } \\
\text { and goods and services. Moreover, it also integrates the } \\
\text { country, facilities economic activity, labor mobility, help } \\
\text { generate employment opportunities, and poverty } \\
\text { alleviation. Transport infrastructure is the center of } \\
\text { political and scientific debate on sustainability due to its } \\
\text { negative externalities both on the environment and quality } \\
\text { of life [20]. Improving the road infrastructure considering } \\
\text { environmental and climate is imperative [21]. }\end{array}$ \\
\hline & $\begin{array}{c}\text { General } \\
\text { Transport } \\
\text { (CCPOSC22) }\end{array}$ & $\begin{array}{l}\text { The number of transport vehicles during the last decades } \\
\text { has increased a lot. This sector is one of the highly } \\
\text { energy-consuming sectors and GHG emission contributors } \\
{[17,28,34] \text {. It is one of the main areas that need mitigation }} \\
\text { and adaptation. }\end{array}$ \\
\hline & Railways (CCPOSC23) & $\begin{array}{l}\text { Despite a potential single major transport mode of } \\
\text { transport contributing to economic growth and national } \\
\text { integration, the Pakistan railway has not been able to } \\
\text { efficiently to provide sustainable transport facilities [22]. } \\
\text { A comprehensive railway rehabilitation plan is warranted } \\
\text { to provide a comparatively environmentally friendly } \\
\text { transport facility. It could be the first step towards green } \\
\text { transport system in Pakistan. }\end{array}$ \\
\hline \multirow{4}{*}{$\begin{array}{l}\text { Urban \& Town } \\
\text { Planning (CСPOC3) }\end{array}$} & $\begin{array}{l}\text { Population and Urbanization } \\
\text { (CCPOSC } 31)\end{array}$ & $\begin{array}{l}\text { Having rampant population growth and unmanaged } \\
\text { urban sprawl in Pakistan, integrated population control } \\
\text { and urban planning is required for successful mitigation } \\
\text { and adaptation measures to climate change [22]. }\end{array}$ \\
\hline & $\begin{array}{l}\text { Integrate Mass-Transit System } \\
\text { (CCPOSC32) }\end{array}$ & $\begin{array}{l}\text { Urban transport management is a critical and challenging } \\
\text { issue [23,24] The development of integrated urban } \\
\text { mass-transit systems in the big cities indispensable to } \\
\text { reduce the number of vehicles and provide sustainable } \\
\text { transport facilities [22]. Also, urban transport needed to be } \\
\text { moved to renewable energy and fuels for a sustainable } \\
\text { urban environment. }\end{array}$ \\
\hline & $\begin{array}{l}\text { Solid Waste Management } \\
\text { (CCPOSC33) }\end{array}$ & $\begin{array}{l}\text { Solid Waste Management (SWM) is one of the biggest } \\
\text { challenging issues, especially in urban areas [35]. } \\
\text { The development of the SWM system must be considered } \\
\text { in the climate change policy. }\end{array}$ \\
\hline & $\begin{array}{l}\text { Water } \\
\text { Management } \\
\text { (CCPOSC34) }\end{array}$ & $\begin{array}{l}\text { Water management in urban areas is not considering } \\
\text { climate change [25]. Rampant urbanization has heightened } \\
\text { the pollution of groundwater in urban areas. There is a } \\
\text { dire need to incorporate the climate change perspectives in } \\
\text { water management such as the provision of clean drinking } \\
\text { water and disposal and recycling of drainage and } \\
\text { wastewater. }\end{array}$ \\
\hline
\end{tabular}


Table 1. Cont.

\begin{tabular}{|c|c|c|}
\hline Criteria & Sub-Criteria & Description \\
\hline \multirow[t]{2}{*}{ Industry (CCPOC4) } & Water Pollution (CCPOSC42) & $\begin{array}{l}\text { Industrial plants cause water pollution. Water treatment } \\
\text { plants need to be constructed to ensure water quality } \\
{[26,27] \text {. Climate change policy must imperatively consider }} \\
\text { the water pollution sourced from the industry. }\end{array}$ \\
\hline & $\begin{array}{l}\text { Land Pollution/Brownfield } \\
\text { (CCPOSC43) }\end{array}$ & $\begin{array}{c}\text { Land pollution and brownfields are a serious issue in } \\
\text { Pakistan [29] but have not attracted enough attention from } \\
\text { the government and policymakers. }\end{array}$ \\
\hline \multirow{3}{*}{ Agriculture (CCPOC5) } & $\begin{array}{c}\text { Crops } \\
\text { (CCPOSC } 51)\end{array}$ & $\begin{array}{l}\text { There is extensive use of fossil fuels, pesticides, herbicides, } \\
\text { fertilizer, and other chemicals in the crop growing process } \\
\text { [31] in economies including Pakistan. Environmentally } \\
\text { friendly crop growing techniques and practices could be } \\
\text { prolific if dovetailed in climate change and agricultural } \\
\text { policy. }\end{array}$ \\
\hline & $\begin{array}{l}\text { Irrigation System } \\
\text { and practices } \\
\text { (CCPOSC52) }\end{array}$ & $\begin{array}{l}\text { The agriculture sector is one of the largest water-using } \\
\text { sectors in most of the regions in the world [36]. Pakistan is } \\
\text { no exception to this. Irrigation system and water use } \\
\text { practices in agriculture are characterized as inefficient [30]. } \\
\text { Having Pakistan an agrarian economy, the irrigation } \\
\text { management system and water use practices in the } \\
\text { agriculture sector needs attention in climate change policy. }\end{array}$ \\
\hline & $\begin{array}{c}\text { Livestock } \\
\text { (CCPOSC53) }\end{array}$ & $\begin{array}{c}\text { The livestock sector also contributes to climate change. } \\
\text { It has a large potential to reduce its GHG emissions [32]. } \\
\text { This sector also needs attention in the climate change } \\
\text { policy. }\end{array}$ \\
\hline
\end{tabular}

\subsection{Climate Change Policy Objectives (Alternatives) in Pakistan}

The goal of the climate change policy of Pakistan is to ensure that mainstream climate change in an economically and socially vulnerable sector in the country and to coxswain Pakistan towards a climate-resilient economy [12]. Figure 1 summarizes the main objectives of the climate change policy of Pakistan [11,12].

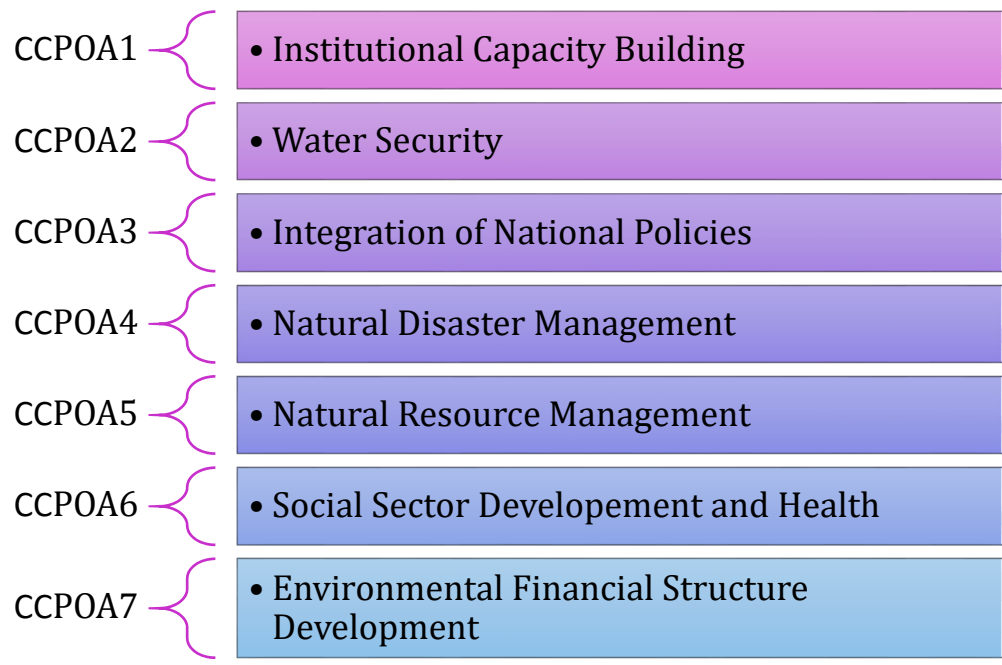

Figure 1. Objectives of the climate change policy of Pakistan. 


\subsubsection{Institutional Capacity Building (CCPOA1)}

Institutions and processes of governance contribute to the shaping and constraining of policymaking and policy implementation in several ways to shift from a high-carbon economy to a low-carbon sustainable economy. Firstly, institutions need to follow the formal rules and regulations and informal norms of a society that set an incentive structure for economic decision-making. Secondly, the intuitions shape the political context for decision-making, empowering some interests, and reducing the influence of others. Thirdly, institutions also play a role in shaping the patterns of thinking and understanding with regard to policy choices. It is important to remove the mismatch between the socio-ecological context and institutional arrangements to pave the way for policy and a technological repose [37] for policy interventions for climate change.

One of the main objectives of the National Climate Change Policy of Pakistan [12] is to "enhance the awareness, skill, and institutional capacity of relevant stakeholders". It points out the need for institutional capacity building in the economy. The pursuance of sustainable economic development, coupled with appropriately addressing the challenges of climate change, is not possible without the efficient, independent, and autonomous functioning of government institutions and departments with an enhanced capacity.

\subsubsection{Water Security (CCPOA2)}

Climate change increases the variability in the water cycle and causes unprecedented and frequent extreme weather events putting huge stress on ecosystems [38]. Water management plays an indispensable central role in adapting the adverse impacts of climate change [39]. The water security of the economy is one of the greatest challenges that the government of Pakistan is facing as the world's sixth largest economy with a population of 212.8 million [40], as it is on the verge of the water crisis. The per capita water availability in Pakistan has decreased to around $1000 \mathrm{~m}^{3}$ in 2016 from 5260 in 1951. Pakistan is an agrarian economy with $70 \%$ of its population directly or indirectly linked to the agriculture sector. In Pakistan, $80 \%$ of 21.2 million hectares of land used for farm cultivation is irrigated. Water is intensively used in agriculture. About $93 \%$ of their water is used in agriculture which is much higher than the global average of around $70 \%$. The pumping of underground water has declined the groundwater tables. About $56 \%$ of the population in Pakistan has access to safe drinking water, but $70 \%$ of people in rural Pakistan have no access to clean water. Moreover, the water supply, in Pakistan, is prone to contamination. Industrial waste receives minimal treatment and leads to water pollution. Amongst over 6000 industries are registered in Pakistan, and 1228 are highly polluting [41]. The climate change policy of Pakistan [11,12] and the national water policy (NWP) [42] consider water security as one of the most important objectives to achieve.

\subsubsection{Integration of National Policies (CCPOA3)}

Mitigation of climate change is the central objective of climate policy all over the globe. With the positive and beneficial factors of the climate change policy, the integration of the climate change policy with other national policies is of fundamental importance for both economic and climate change perspectives. It is primarily pivotal to integrate a climate change policy with other inter-related national policies. It can help achieve the objective of other policies as well. For instance, the prime objective of a development policy is social development; the objectives of energy, technology development, and air pollution policies are energy security, technological development, and reducing air pollution, respectively [37]. For an effective climate change policy in terms of mitigation and adaption, it is necessary to bring national, provincial and local policies into the mainstream and widen the goals within the national and local contexts. Especially in developing counties, the integration of climate change policies into development planning can help increase cooperation and coordination across the movement institutions at all levels [43]. 


\subsubsection{Natural Disaster Management (CCPOA4)}

There is a strong link between climate change policies and disaster risk management. These two complement each other [44]. The disaster management policy is related to risks, vulnerability, and resilience issues based on a community-led approach to disaster management [45]. The objective of the climate change policy is to dovetail all such structural and non-structural initiatives within the holistic framework of disaster risk reduction. It makes the national disaster management indispensable to make Pakistan a disaster-resilient economy.

\subsubsection{Natural Resource Management (CCPOA5)}

Natural resources are natural materials, such as coal, oil, water, air, fish, animals, land, and timber, and natural resource management refers to the supervision or handling of these natural resources. In recent decades, natural resource management has attracted increasing attention, especially in Asian economies. It has become increasingly challenging in the face of climate change and environmental damage. The development of infrastructure, advancement in extraction techniques, expansion of product markets, and increased burden on natural resources has compromised the natural resource base. Consequently, the land quality, water, and forests are threatened. The haphazard use of natural resources has posed serious threats to the viability and sustainability of natural resources [46]. One of the main objectives of the climate change policy in Pakistan is to promote the conservation of natural resources to ensure long-term sustainability in the economy [11,12].

\subsubsection{Social Sector Development and Health (CCPOA6)}

Social sector development-the safety and health of the masses-is a major objective to achieve sustainable development goals (SDGs). Climate change mitigation plays a pivotal role in achieving the SDGs [1]. However, the objective could not be achieved by ensuring environmental protection in the economy. An assessment of the health vulnerability of communities, especially in the areas adversely affected climate change, is important. In addition to this, the building capacities of the masses to reduce their vulnerabilities are also an area of great importance. The incorporation of health-related climate change issues in national health plans would add to the efforts of creating resilience [12]. Environmental education is also another area that the government of Pakistan is putting efforts into. Figure 2 shows how the social, economic, and environmental dimensions of sustainable development need to be integrated into climate change policy domain.

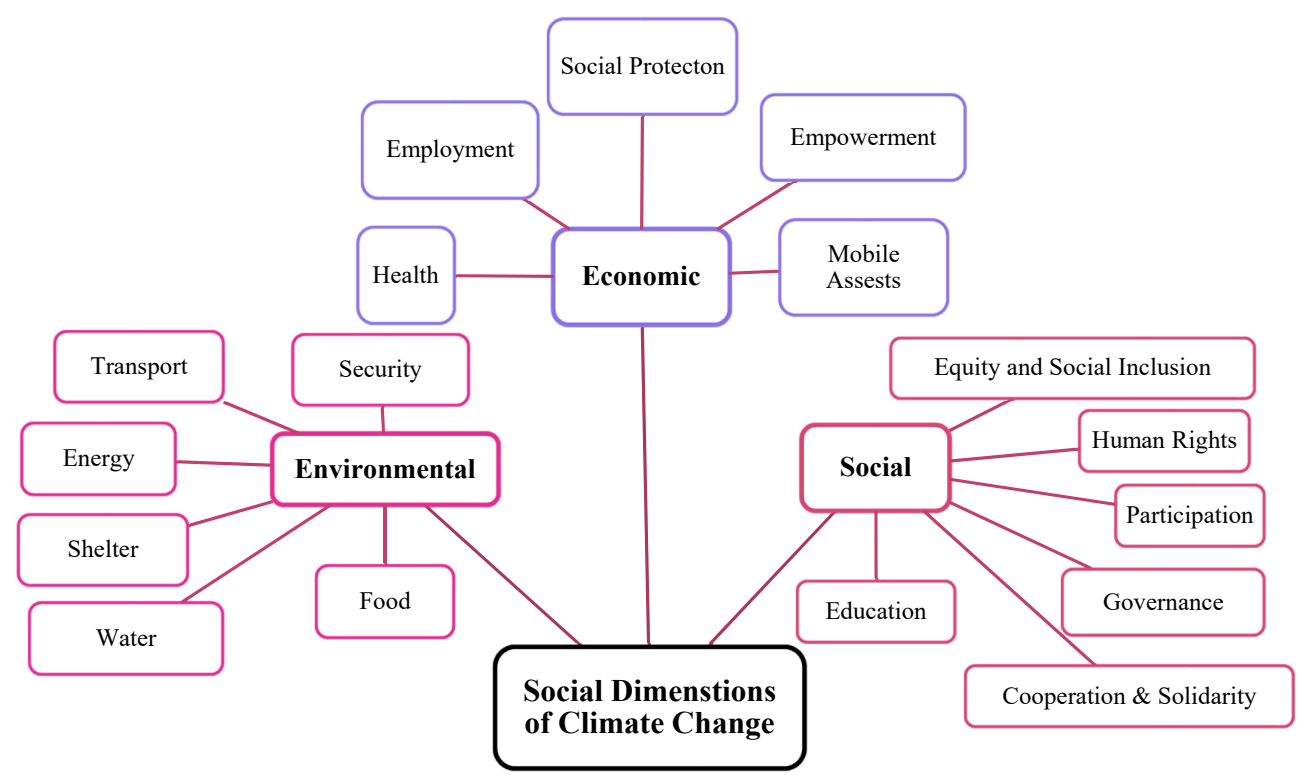

Figure 2. Social dimensions of climate change in the framework of sustainable development [47]. 


\subsubsection{Environmental Financial Structure (CCPOA7)}

A climate change response requires significant financial resources. Governments must plan and execute the national and provincial budgets and harmonize development spending with climate change and environmental policy [48]. The National Climate Change Policy of Pakistan [12] indorses the effective use of opportunities, especially financial, at national and international levels. The government of Pakistan realizes the importance of climate budgeting and is focused on integrated climate budgeting with policies and planning in Pakistan [44,48]. The government is focused on integrating climate budgeting with policy and planning and is taking unprecedented initiatives for climate-related development planning [44,48].

\section{Methodological Framework for Climate Change Policy Objective Prioritization}

The present study utilized MCDA tools for the prioritization of the CCPOAs of the NCCP of Pakistan. The MCDA tools, such as the fuzzy AHP and fuzzy VIKOR, provide extended support in decision-making by providing profound insights into a decision problem $[49,50]$. There are various multi-criteria decision methods (MCDM)-based studies which are available in the literature which has focused on solving the complicated decision-making problem [51,52]. The literature on research related to climate change and the environmental policy design framework are summarized in Table 2.

The literature review regarding the use and application of MCDMs in environmental management, the selection of energy sources, and prioritization, shows that MCDMs are the most commonly and widely used analytical tools to help out the policymakers, experts, and stakeholders in their respective decision-making (see the climate change-related policy analyses in Table 2). Due to the flexibility and efficiency of these MCDM tools, this study used a fuzzy AHP and fuzzy VIKOR method for the analysis. The framework of the study is shown in Figure 3. 
Table 2. A literature review of studies using multi-criteria decision methods (MCDMs).

\begin{tabular}{|c|c|c|}
\hline Study & Purpose & MCDA Method \\
\hline Papapostolou et al. [53] & $\begin{array}{l}\text { Analysis of cross-border renewable energy } \\
\text { cooperation strategies. }\end{array}$ & $\begin{array}{l}\text { AHP, SWOT, } \\
\text { Fuzzy TOPSIS }\end{array}$ \\
\hline Salimi et al. [54] & $\begin{array}{l}\text { Examination of the role of advertising types on } \\
\text { water consumption behavior. }\end{array}$ & $\begin{array}{l}\text { Fuzzy AHP, } \\
\text { Fuzzy VIKOR }\end{array}$ \\
\hline Dao et al. [55] & $\begin{array}{l}\text { Assessment of environmental conflicts in the } \\
\text { mining industry. }\end{array}$ & Fuzzy AHP, Fuzzy TOPSIS \\
\hline Shumaiza et al. [56] & $\begin{array}{l}\text { Application of MCDA approaches on the } \\
\text { selection of waste treatment and site selection } \\
\text { for the thermal power station. }\end{array}$ & Fuzzy VIKOR, Fuzzy TOPSIS \\
\hline Solangi et al. [57] & $\begin{array}{l}\text { Analysis of the solar power project site } \\
\text { selection for renewable energy production. }\end{array}$ & $\begin{array}{c}\text { AHP, } \\
\text { Fuzzy VIKOR }\end{array}$ \\
\hline Solangi et al. [16] & $\begin{array}{c}\text { Evaluation of the strategies for sustainable } \\
\text { energy planning. }\end{array}$ & $\begin{array}{l}\text { SWOT-AHP, } \\
\text { Fuzzy TOPSIS }\end{array}$ \\
\hline Ahmed et al. [58] & $\begin{array}{l}\text { Environmental implications of crop-stubble } \\
\text { burning and its implications on climate change. }\end{array}$ & AHP, TOPSIS \\
\hline Wang et al. [59] & $\begin{array}{l}\text { Sustainable energy conservation technologies } \\
\text { selection for agriculture residue. }\end{array}$ & $\begin{array}{l}\text { Fuzzy AHP, } \\
\text { VIKOR }\end{array}$ \\
\hline Shah et al. [15] & $\begin{array}{l}\text { Examination of barriers to the adoption of } \\
\text { cleaner energy production technologies. }\end{array}$ & $\begin{array}{l}\text { Modified Delphi, } \\
\text { Fuzzy AHP }\end{array}$ \\
\hline Busico et al. [60] & $\begin{array}{l}\text { Modeling actual and future climate change } \\
\text { accounting water resources attention role. }\end{array}$ & GIS, AHP \\
\hline Xu et al. [61] & $\begin{array}{l}\text { Analysis of economic viability and } \\
\text { environmental efficiency of the hydrogen } \\
\text { production process for decarbonization of } \\
\text { energy systems. }\end{array}$ & Fuzzy AHP, Fuzzy TOPSIS \\
\hline Suganthi [62] & $\begin{array}{c}\text { Multi-expert and multi-criteria analysis of } \\
\text { sectoral investment for sustainable } \\
\text { development. }\end{array}$ & Fuzzy AHP, VIKOR, DEA \\
\hline Udie et al. [63] & $\begin{array}{l}\text { Vulnerability assessment of climate change } \\
\text { impact on critical oil \& gas unfractured. }\end{array}$ & AHP \\
\hline Champalle et al. [64] & Prioritization of climate change adaptation. & MCDA, NCA \\
\hline Kim and Chung [65] & $\begin{array}{c}\text { Prioritizing climate change adaptation } \\
\text { strategies. }\end{array}$ & VIKOR \\
\hline Chung and Kim [66] & $\begin{array}{l}\text { Prioritization of locations of treated wastewater } \\
\text { use regarding climate change scenarios. }\end{array}$ & $\begin{array}{l}\text { WSM, TOPSIS, Fuzzy } \\
\text { TOPSIS, }\end{array}$ \\
\hline Kim and Chung [67] & $\begin{array}{l}\text { Assessing the vulnerability of water supply to } \\
\text { climate change and variability in South Korea. }\end{array}$ & Fuzzy VIKOR \\
\hline Kaya and Kahraman [68] & $\begin{array}{c}\text { Renewable energy planning for alternative } \\
\text { energy policies. }\end{array}$ & $\begin{array}{l}\text { Fuzzy VIKOR, } \\
\text { AHP }\end{array}$ \\
\hline
\end{tabular}




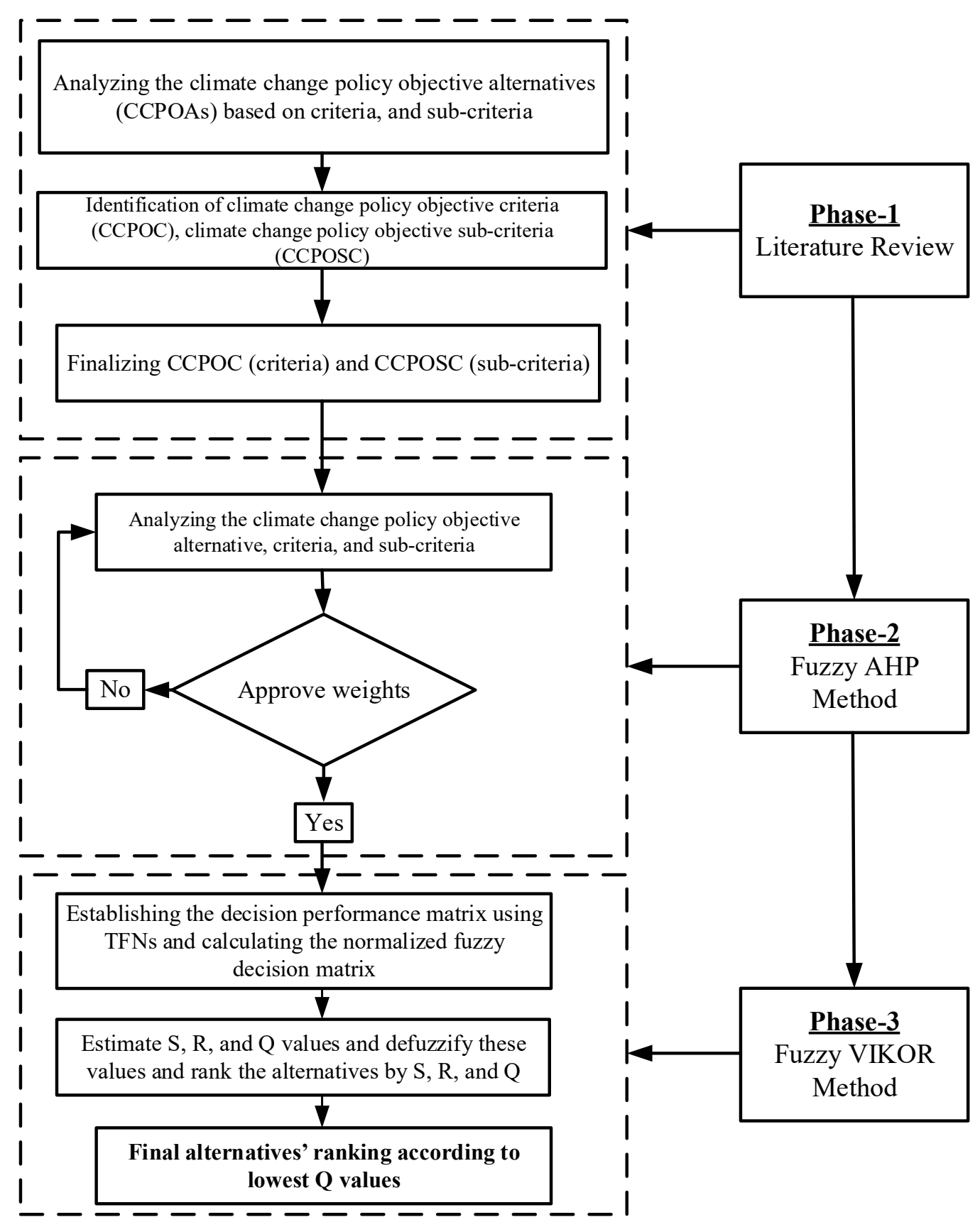

Figure 3. Research framework based on a fuzzy analytical hierarchy process (AHP) and fuzzy VIseKriterijumska Optimizacija I Kompromisno Resenje (VIKOR).

\subsection{Fuzzy AHP}

An analytic hierarchy process (AHP) [69] is an efficient decision support method developed to help in decision-making. In AHPs, the problem is broken down into the problem solution and then grouped and arranged into a hierarchical structure. AHPs uses "pairwise comparisons" and matrix algebra to weight criteria. The decision is made based on the estimated weights of the evaluative criteria [69]. The perception or opinion of experts is the main input of the AHP method that unveils its factor of subjectivity in making retrieval decisions. Moreover, this method also considers data validity with inconsistent limits [70]. Therefore, extensive uncertainty and vagueness in the assessment can affect the accuracy of the data and the results obtained. Usually, the decision-makers cannot be explicit 
about their preferences because of the fuzzy nature of the comparison process. So, customarily they find it confident to give interval judgments than the fixed value judgments.

The fuzzy set theory may be a more suitable method to deal with uncertainty [49]. Zadeh [71] introduced a fuzzy set theory and enabled the experts to express the linguistic terms in the decision-making process to overcome the ambiguity, vagueness, and subjectivity of human judgment. Due to the complex and dynamic nature of the real world, there is a possibility that the goals, the constraints, and the consequences of probable and possible actions are not known precisely [72]. In this scenario, fuzzy decision-making refers to the collection of a single or multi-criteria method aimed at selecting the best alternative given the imprecise, vague, and incomplete data [73]. A fuzzy AHP is similar to the AHP method. To avoid this discrepancy, fuzzy AHPs were developed with fuzzy logic theory. The only difference between an AHP and fuzzy AHP is that the latter sets the AHP scale into the fuzzy triangle scale for prioritization [50].

A fuzzy AHP is a popular method amongst decision analysts and experts, yet it also prone to some limitations. A fuzzy AHP requires more complex estimations. A fuzzy AHP has an advantage over other MCDM methods—such as fuzzy Technique of Order Preference Similarity to the Ideal Solution (TOPSIS), which uses a pairwise comparison for the criteria and sub-criteria-in that alternatives can be made in fuzzy AHPs. Moreover, in a fuzzy AHP analysis, the priority of criterion and alternative can be equal to zero. Due to this advantage, it is not recommended to use it. However, given the consistency of the decision-makers in determining the data, fuzzy AHPs can produce the same results as with fuzzy TOPSIS. Despite some shortcomings, fuzzy AHPs are one of the favorite methods used for decision analyses [74].

Following the six steps of fuzzy AHP has been followed for the prioritization of environmental and climate change policy objectives:

Step I: Construct the hierarchical structure of the problem.

Step II: The pairs of criteria, Equation (1), sub-criteria, Equation (2), and alternatives, Equation (3) are evaluated and compared:

$$
A=\left[\begin{array}{cccc}
a_{11} & a_{12} & \ldots & a_{1 m} \\
a_{21} & a_{22} & \ldots & a_{2 m} \\
\ldots & \ldots & \ldots & \ldots \\
a_{m 1} & a_{m 2} & \ldots & a_{m m}
\end{array}\right]
$$

where $a_{i j}=1$ for every $i=j,(i, j=1,2,3, \ldots, m)$, and $a_{i j}=\frac{1}{a_{j i}}$.

$$
A_{k}=\left[\begin{array}{cccc}
a_{11} & a_{12} & \ldots & a_{1 k_{j}} \\
a_{21} & a_{22} & \ldots & a_{2 k_{j}} \\
\ldots & \ldots & \ldots & \ldots \\
a_{k_{j} 1} & a_{k_{j} 2} & \ldots & a_{k_{j} k_{j}}
\end{array}\right]
$$

where criterion $\left(C_{j}\right)$ comprises the $k_{j}$ criteria, and

$$
\mathcal{B}_{k}=\left[\begin{array}{cccc}
a_{11} & a_{12} & \ldots & a_{1 N} \\
a_{21} & a_{22} & \ldots & a_{2 N} \\
\ldots & \ldots & \ldots & \ldots \\
a_{N 1} & a_{N 2} & \ldots & a_{N N}
\end{array}\right]
$$

where $N$ is the number of alternatives related to each $K$ criteria; $k=1,2,3, \ldots, K$. 
Step III: The weights of three matrices in Step 2 are determined gradually, using the extent analysis, fuzzy arithmetic [75], and the extension principle. All resulting weights are normalized as:

$$
w_{i}=\sum_{j=1}^{m} a_{i j} \otimes\left[\sum_{k=1}^{m} \sum_{i=1}^{m} a_{k l}\right]^{-1}
$$

where $i=1,2,3, \ldots, m$.

$$
w_{j}^{\prime}=\left(\sum_{l=1}^{k_{j}} a_{i l} \otimes\left[\sum_{i=1}^{k_{j}} \sum_{l=1}^{k_{j}} a_{i l}\right]^{-1}\right) \otimes w_{j}
$$

where $j=1,2,3, \ldots, m ; p=1,2,3, \ldots, k_{j}$.

$$
\Phi=\left(w_{1}^{1}, w_{1}^{2}, \ldots, w_{1}^{k_{1}} ; w_{2}^{1}, w_{2}^{2}, \ldots, w_{2}^{k_{1}} ; \ldots ; w_{j}^{1}, w_{j}^{2}, \ldots, w_{j}^{k_{j}} ; \ldots ; w_{m}^{1}, w_{m}^{2}, \ldots, w_{m}^{k_{m}}\right)
$$

In Equation (6), ' $\Phi$ ' represents the sub-criteria weights with the total length " $K$ ".

$$
\Phi=\left(\Phi_{1}, \Phi_{2}, \ldots, \Phi_{K}\right)
$$

Step IV: In this step, the aggregation principal is applied to reduce the two hierarchy tiers (i.e., criteria and sub-criteria) to a single tier:

$$
K=\sum_{j=1}^{m} k_{j}
$$

where $C_{1}, C_{2}, \ldots, C_{m}$ is set of the $m$ criteria, with its sub-criteria; $k_{j}$ is the number of sub-criteria of the $j$-th criterion.

Step V: This step comprises an estimation of the fuzzy decision matrix and fuzzy performance matrix. The fuzzy decision matrix is obtained from the estimations of the fuzzy extent analysis in Step 3 for the alternatives as:

$$
Y=\left[\begin{array}{llll}
y_{11} & y_{12} & \ldots & y_{1 K} \\
y_{21} & y_{22} & \ldots & y_{2 K} \\
\ldots & \ldots & \ldots & \ldots \\
y_{N 1} & y_{N 2} & \ldots & y_{N K}
\end{array}\right]
$$

The fuzzy performance matrix indicates the overall performance of each alternative related to all sub-criteria:

$$
Z=\left[\begin{array}{cccc}
y_{11} \otimes \Phi_{1} & y_{12} \otimes \Phi_{2} & \ldots & y_{1 K} \otimes \Phi_{K} \\
y_{21} \otimes \Phi_{1} & y_{22} \otimes \Phi_{2} & \ldots & y_{2 K} \otimes \Phi_{k} \\
\ldots & \ldots & \ldots & \ldots \\
y_{N 1} \otimes \Phi_{1} & y_{N 2} \otimes \Phi_{2} & \ldots & y_{N K} \otimes \Phi_{K}
\end{array}\right]
$$

Step VI: The ultimate values of the alternatives are obtained in the form of triangular fuzzy numbers:

$$
F_{i}=\sum_{j=1}^{K} y_{i j} \otimes \Phi_{j}
$$

Step VII: The last step is defuzzification: the alternative with the greatest weight is deemed to be the optimal one. The sum of the weights of all the alternatives equals zero:

$$
\operatorname{Defuzzify}(A)=\frac{(d-l)+(s-l)}{3}+l
$$

\subsection{Fuzzy VIKOR}

The VIseKriterijumska Optimizacija I Kompromisno Resenje (VIKOR) was developed by Opricovic in 1980 [76]. It is a multi-criteria optimization and compromise solution method used in an MCDA. The idea behind the development of the VIKOR method was to address decisive issues with conflicting 
criteria. Since it is not possible to sort out the assumption that compromise is acceptable in conflict resolution, as the decision-makers long for the solution closest to the ideal, the solution is assessed according to the ideal to set all criteria [77]. The VIKOR prioritizes the alternative and identifies the solution as the closest compromise to the ideal. It provides a complete view of the suitability of options and enables the decision-maker to bring subjective elements out of the equation [78]. The VIKOR method of MCDMs was extended over the years in different studies. Opricovic and Tzeng [79] introduced a new model based on VIKOR and TOPSIS methods to defuzzify within the MCDM model with combined fuzzy criteria and a set up of crisp. In Opricovic and Tzeng [80], the authors integrated the VIKOR technique with triangular fuzzy numbers (TFNs) to examine the planning strategies. In another study, Opricovic and Tzeng [81] introduced fuzzy VIKORs with incomplete information to examine the land-use strategies used for decreasing economic and social costs that occurred due to potential natural hazards. This solution would assess decision-makers to obtain and reach a final decision goal. The compromise solution is a feasible solution to a decision problem. The compromise solution means an agreement established by mutual concessions [82]. The following are the key steps of the fuzzy VIKOR methodology.

Step I: Construct the fuzzy performance matrix and the weight vector as:

$$
\begin{array}{r}
\widetilde{M}=\begin{array}{c}
A_{1} \\
A_{2} \\
\vdots \\
A_{n}
\end{array}\left[\begin{array}{cccc}
c_{1} & c_{2} & \cdots & c_{n} \\
\widetilde{F}_{11} & \widetilde{F}_{12} & \ldots & \widetilde{F}_{1 n} \\
\widetilde{F}_{21} & \widetilde{F}_{22} & \ldots & \widetilde{F}_{2 n} \\
\vdots & \vdots & \ddots & \vdots \\
\widetilde{F}_{m 1} & \widetilde{F}_{m 2} & \cdots & \widetilde{F}_{m n}
\end{array}\right] \\
\widetilde{\Omega}=\left[\begin{array}{llllll}
\widetilde{\omega}_{1} & \widetilde{\omega}_{2} & \ldots & \widetilde{\omega}_{n}
\end{array}\right] \text { and } \sum_{j=1}^{n} \omega_{j}=1
\end{array}
$$

In Equation (1), $A_{i}=$ alternatives $i, i=1, \ldots, m$;

$c_{j}=$ criterion or attribute $j, j=1, \ldots, n$;

$\widetilde{F}_{i j}=$ fuzzy performance rating of alternatives (A's) with respect to criterion (c's);

$\widetilde{\Omega}=$ the fuzzy weight for each criterion. Here, $\widetilde{F}_{i j}$ can be defined as $\widetilde{F}_{i j}=\left(l_{i j}, m_{i j}, r_{i j}\right)$ and as a TFN.

Step II: The ideal $\widetilde{F}_{i}^{*}=\left(l_{i}^{*}, m_{i}^{*}, r_{i}^{*}\right)$ and the nadir $\widetilde{F}_{i}^{\circ}=\left(l_{i}^{\circ}, m_{i}^{\circ}, r_{i}^{\circ}\right)$ values of each criterion function according to the benefit or cost functions were determined. The set of criteria expressing benefits (good or positive effects) is symbolized as $I^{\beta}$, and a set of criteria expressing costs (unfavorable or negative effects) is symbolized as $I^{\gamma}$.

$$
\begin{aligned}
& \widetilde{F}_{i}^{*}=\max _{j} \widetilde{F}_{i j}, \widetilde{F}_{i}^{o}=\min _{j} \widetilde{F}_{i j} \text { for } i \in I^{\beta} \\
& \widetilde{F}_{i}^{*}=\min _{j} \widetilde{F}_{i j}, \widetilde{F}_{i}^{o}=\max _{j} \widetilde{F}_{i j} \text { for } i \in I^{\gamma} \\
& \left\{\begin{array}{c}
\widetilde{F}_{i}^{*}=\max _{j} \widetilde{F}_{i j}, \quad \widetilde{F}_{i}^{o}=\min _{j} \widetilde{F}_{i j} \quad \text { for } i \in I^{\beta} \\
\widetilde{F}_{i}^{*}=\min _{j} \widetilde{F}_{i j}, \quad \widetilde{F}_{i}^{o}=\max _{j} \widetilde{F}_{i j} \quad \text { for } i \in I^{\gamma}
\end{array}\right.
\end{aligned}
$$

Step III: The normalized fuzzy differences $\left(\widetilde{\delta}_{i j}\right)$ were estimated.

$$
\begin{aligned}
& \widetilde{\delta}_{i j}=\frac{\widetilde{F}_{i}^{*}(-) \widetilde{F}_{i j}}{r_{i}^{+}-l_{i}^{\circ}} \text { for } i \in I^{\beta} \\
& \widetilde{\delta}_{i j}=\frac{\widetilde{F}_{i j}(-) \widetilde{F}_{i}^{*}}{r_{i}^{\circ}-l_{i}^{*}} \text { for } i \in I^{\gamma} \\
& \left\{\begin{array}{c}
\widetilde{\delta}_{i j}=\frac{\widetilde{F}_{i}^{*}(-) \widetilde{F}_{i j}}{r_{i}^{+}-l_{i}^{\circ}} \quad \text { for } i \in I^{\beta} \\
\widetilde{\delta}_{i j}=\frac{\widetilde{F}_{i j}(-) \widetilde{F}_{i}^{*}}{r_{i}^{\circ}-l_{i}^{*}} \quad \text { for } i \in I^{\gamma}
\end{array}\right.
\end{aligned}
$$


Step IV: The values $\widetilde{S}_{j}=\left(S_{j}^{l}, S_{j}^{m}, S_{j}^{r}\right)$ and $\widetilde{R}_{j}=\left(R_{j^{\prime}}^{l} R_{j}^{m}, R_{j}^{r}\right)$ were estimated:

$$
\begin{aligned}
& \widetilde{S}_{j}=\sum_{i=1}^{n} \widetilde{\omega}_{i}(\times) \widetilde{\delta}_{i j}, \\
& \widetilde{R}_{j}=\max _{i} \widetilde{\omega}_{i}(\times) \widetilde{\delta}_{i j} .
\end{aligned}
$$

Step V: The next step is to estimate the values $\widetilde{\varphi}_{j}=\left(\varphi_{j^{\prime}}^{l}, \varphi_{j}^{m}, \varphi_{j}^{r}\right)$ :

$$
\widetilde{\varphi}_{j}=v \frac{\widetilde{S}_{j}(-) \widetilde{S}^{*}}{S^{\circ r}-S^{* l}}(+)(1-v) \frac{\widetilde{R}_{j}(-) \widetilde{R}^{*}}{R^{\circ r}-R^{* l}}
$$

In the above equation, $\widetilde{S}^{*}=\min _{j} \widetilde{S}_{j}, S^{\circ r}=\max _{j} S_{j}^{r} \widetilde{R}^{*}=\min _{j} \widetilde{R}_{j}$ and $R^{\circ r}=\max _{j} R_{j}^{r}$. Additionally, $v$ is a weight for the strategy of "the majority" criteria $\left(\widetilde{S}_{j}\right)$, and $1-v$ is the weight of the individual regret $\left(\widetilde{R}_{j}\right)$.

Step VI: Defuzzify $\widetilde{S}_{j}, \widetilde{R}_{j}$, and $\widetilde{\varphi}_{j}$.

Step VII: The next step is to rank the alternatives, sorting them by their crisp values in descending order. The results would be in three ranking lists, $\{A\}_{S},\{A\}_{R}$, and $\{A\}_{\varphi}$, according to $\operatorname{crisp}(S)$, $\operatorname{crisp}(R)$, and $\operatorname{crisp}(\varphi)$, respectively.

Step VIII: Suggest a compromise solution for the alternative $A^{(1)}$ — the optimal solution by the measure $\varphi$ if the following conditions hold:

C1. "Optimal benefit": $O b \geq M \varphi$.

where $O b=\left[\varphi\left(A^{(2)}-\varphi\left(A^{(1)}\right] /\left[\varphi\left(A^{(m)}-\varphi\left(A^{(1)}\right]\right.\right.\right.\right.$ is the advantage rate alternative $A^{(1)}$ (ranked first), compared with the alternative in the second position, $A^{(2)}$ in $\{A\}_{\varphi}$ and $M \varphi=1 /(m-1)$.

C2: The acceptable stability of the decision-making is determined as an alternative, and the $A^{(1)}$ must also be the best ranked by $S$ or $R$.

If one of the above conditions is not fulfilled, a set of compromise solutions (CS) is suggested which consists of:

CS1: The alternative $A^{(1)}$ and $A^{(2)}$ if only $\mathrm{C} 2$ is not satisfied.

CS2: The alternatives $A^{(1)}, A^{(2)}, \ldots, A^{(M)}$ if condition $\mathrm{C} 1$ is not satisfied: $A^{(M)}$ is determined by the relation $\left[\varphi\left(A^{(M)}-\varphi\left(A^{(1)}\right] /\left[\varphi\left(A^{(m)}-\varphi\left(A^{(1)}\right]<M \varphi\right.\right.\right.\right.$ for the maximum $M$ (the position of these alternatives in closeness).

\subsection{Proposed Approach to the Problem}

This section illustrates the analytic approach to assess and prioritize the environmental and climate change policy objectives in Pakistan. First, an appropriate criterion is needed to be defined to reach the final goal set, i.e., to prioritize the environmental and climate change alternative policy objectives. After selecting the criteria and sub-criteria and defining alternative policy objectives, fuzzy pairwise comparisons matrices have been designed. For this purpose, policymakers, environmental policy experts, agriculture experts, industrialists, businesses, energy experts, transporters, urban planners, transport experts, economists, and academic researchers have been interviewed. Their expert opinions contributed to the design of the fuzzy pairwise comparison matrices. Moreover, the information revealed by the experts enabled the application of a fuzzy AHP and enriched the understanding and decision-making in the climate change policy objective prioritization.

As in the MCDA, it is important to engage qualified and relevant experts to obtain a meaningful and expert opinion. Following Solangi et al. [16,74] and Waqas et al. [83], the researchers in this study consulted with 15 experts to participate and provide profound and critical opinions through a webmail service for the analysis of the criteria, sub-criteria, and alternatives. The demographic 
information of the experts is given in Appendix A (Table A1). All of the experts were requested to make a pairwise comparison matrix using the TFNs scale for fuzzy AHP method. Then, the experts were again consulted to weight the alternatives based on the sub-criteria of the study. In the study, the group decision-making has been used using a geometric mean approach to identify and analyze the final ranking of criteria, sub-criteria, and alternatives.

\section{Results and Discussion}

This section comprises the results of the fuzzy AHP and fuzzy VIKOR. The prioritization of the CCPOC with respect to the goal, ranking of CCPOSCs with respect to the CCPOCs, and the overall ranking of the CCPOAs is presented with a comprehensive discussion with special reference to the Pakistan economy.

\subsection{Results of the Fuzzy AHP Analysis of the Climate Change Policy Objective Criteria (CCPOC (Criteria))}

Firstly, the ranking of the criteria with respect to the goal is obtained by using fuzzy AHP. Pairwise comparisons with respect to goal and criteria are given in Appendix B from Tables A2-A7. Based on the information and feedback provided by the experts, the fuzzy AHP analysis concluded that the ranking of the criteria for the climate change policy objectives were CCPOC1 $>$ CCPOC2 > CCPOC $4>$ CСPOC5 $>$ ССРОC 3 . The results of the ranking of areas of mitigation are presented in Figure 4. This ranking shows that the energy sector (CCPOC1) in Pakistan's economy is the most important sector to focus on with regard to the formulation and implementation of mitigation policies aiming to reduce $\mathrm{CO}_{2}$ emissions. Secondly, the transport sector (CCPOC2) with a weight of 0.220 is a pivotal sector that requires attention in terms of the implementation of mitigation efforts as it is the second major contributor to the Green House Gases (GHGs) emission in the country. The industrial sector (CCPOC4) stood at third with weight of 0.214 in the fuzzy AHP ranking followed by the agriculture sector (CCPOC5) and urban and town planning (CCPOC3) with weights of 0.171 and 0.160 , respectively.

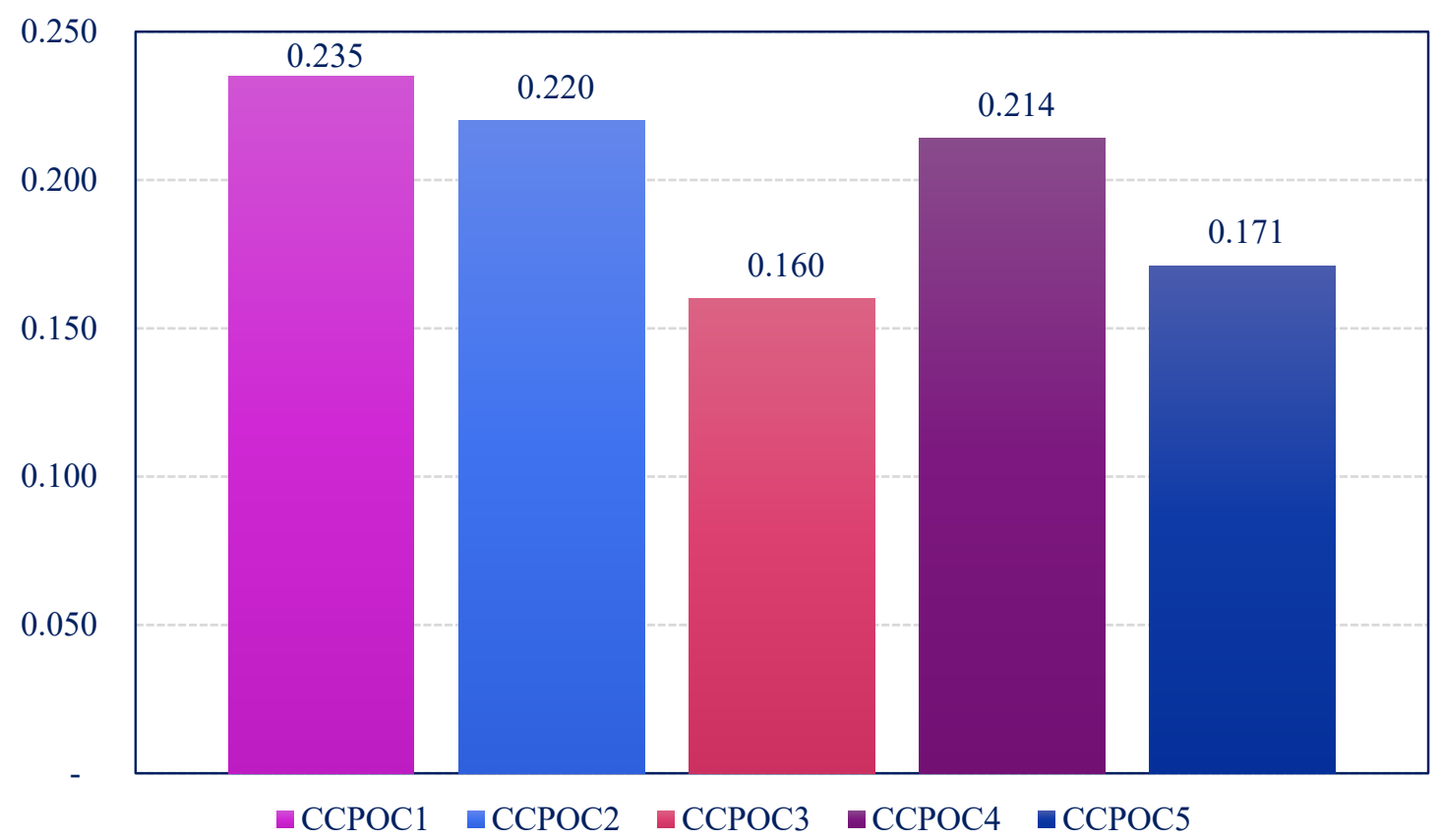

Figure 4. Ranking of the climate change policy objective criteria (CCPOC) with respect to the goal.

\subsection{Results of the Fuzzy AHP Analysis of Climate Change Policy Objectives Sub-Criteria (CCPOSC)}

After estimating the weights in terms of ranking the climate change policy objective criteria (CCPOC) with respect to the goal, in the next step, the weights for the ranking of the climate change 
policy objective sub-criteria (sub-criteria (CCPOSC)), with respect to respective CCPOC, were estimated. The following subsections represent the results of the fuzzy AHP ranking results.

\subsubsection{Ranking of the Sub-Criteria (CCPOSC1i's) with Respect to the Energy Criteria (CCPOC1)}

Figure 5 shows the rankings of the CCPOSC (sub-criteria) with respect to the energy criteria (CCPOC1). It reveals that energy production (CCPOSC11) is the most critical sector for mitigation policy formulation and implementation, followed by the fiscal reforms sub-criteria (CCPOSC12) and transmission and distribution sub-criteria (CCPOSC13). This ranking of the sub-criteria is in congruence with the actual state of the energy sector in Pakistan. Electricity production in Pakistan's economy mostly comprises thermal sources such as oil and gas. In 2013 , about $64 \%$ of their electricity was produced from thermal sources. The share of thermal sources in electricity production was the same in 2018. However, the proportion of electricity produced from hydro sources has decreased from $31 \%$ in 2013 to $27 \%$ in 2018 , whereas the electricity from nuclear sources increased from $5 \%$ to $7 \%$ in the same period. When it comes to renewable energy, the electricity generated from renewable sources was $0 \%$, but it increased to $2 \%$ of the electricity produced in Pakistan in 2018 [17]. This is very little in terms of coping with the menace of global warming and climate change $[15,16,18]$.

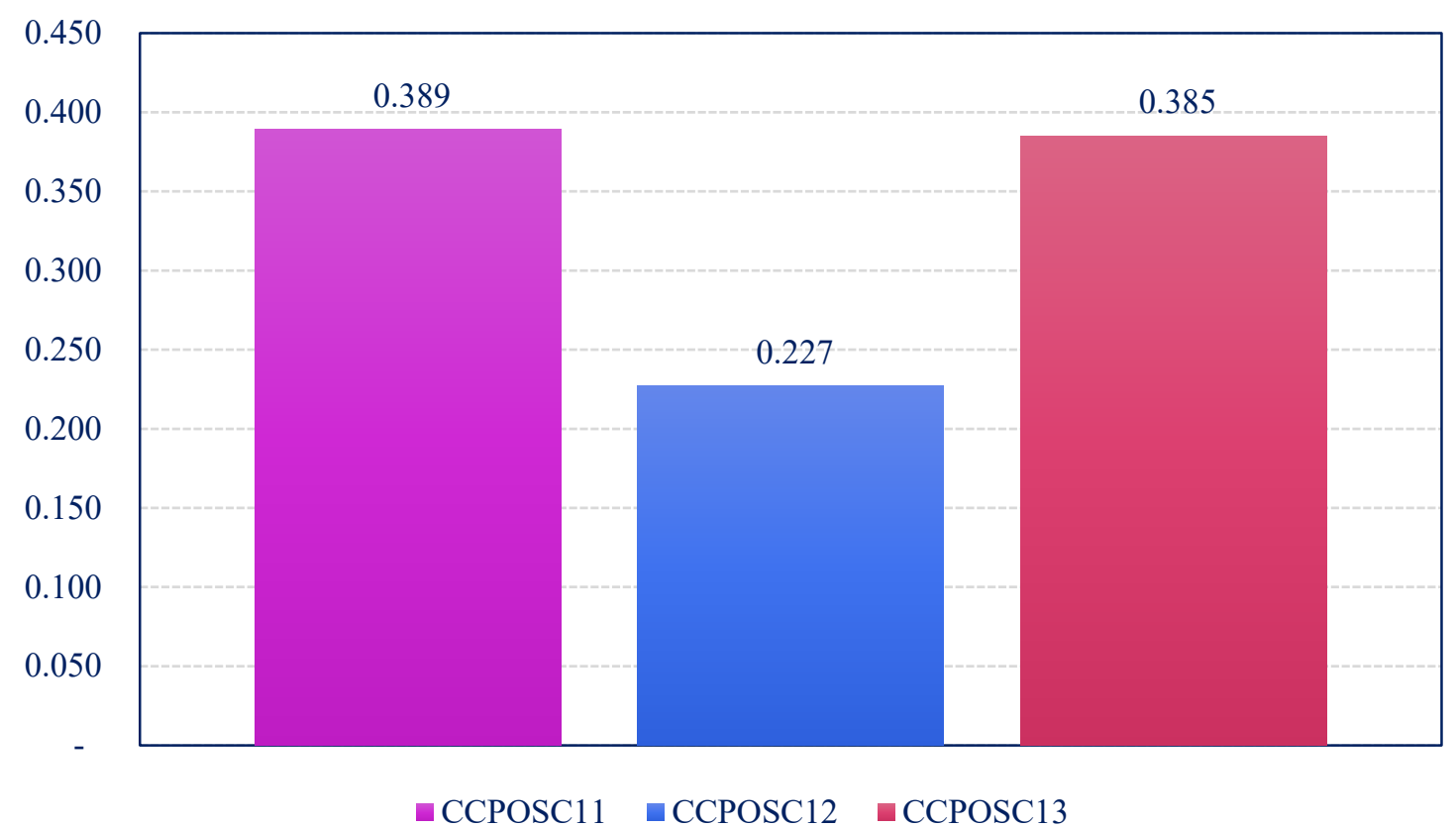

Figure 5. Ranking of the climate change policy objective sub-criteria with respect to the energy criteria (CCPOC1).

The second-ranked sub-area of the climate change policy objectives (sub-criteria) regarding CCPOC1 indicates its relevance with the climate change policy objectives in Pakistan. It is because the transmission and distribution system in Pakistan is inefficient as electricity line losses are very high $[18,84]$. The up-gradation of the transmission lines and improvement in the distribution system would help in resolving energy crises. Until now the focus of the government has been to increase the productive capacity. However, focus on CCPOSC12 and CCPOSC13 would increase the efficiency and increase the efficient transmission and distribution of the electricity produced in the economy.

\subsubsection{Ranking of the Sub-Criteria (CCPOS2i's) with Respect to the Transport Criteria (CCPOC2)}

The ranking of the CCPOSC2s (sub-criteria) considering the transport criteria (CCPOC2) is displayed in Figure 6. The fuzzy AHP results unfold railways (CCPOSC23, the most preferred sub-area (sub-criteria) as needing to be addressed. Rail as compared to road transport is more sustainable in 
terms of carbon emission, noise pollution, energy consumption, and use of space. However, road transport, in Pakistan, is dominant, carrying $91 \%$ and $96 \%$ of national passengers and freight traffic, respectively. Though the transport sector is playing a pivotal role in the economy, it is one of the major contributors to national emissions as it is responsive to about $21 \%$ of national emissions [85]. Out of the total fuel combustion, the transport sector contributes about $29 \%$ of the $\mathrm{CO} 2$ emissions [86]. Despite its role in the sustainable transport system in the economies, the railway system in Pakistan is not efficient and has a very limited role in transport services. It is very important to overhaul the railway system and develop it to reduce people using road transport and to reduce emissions and increase the efficiency in the overall transport system for a sustainable environment.

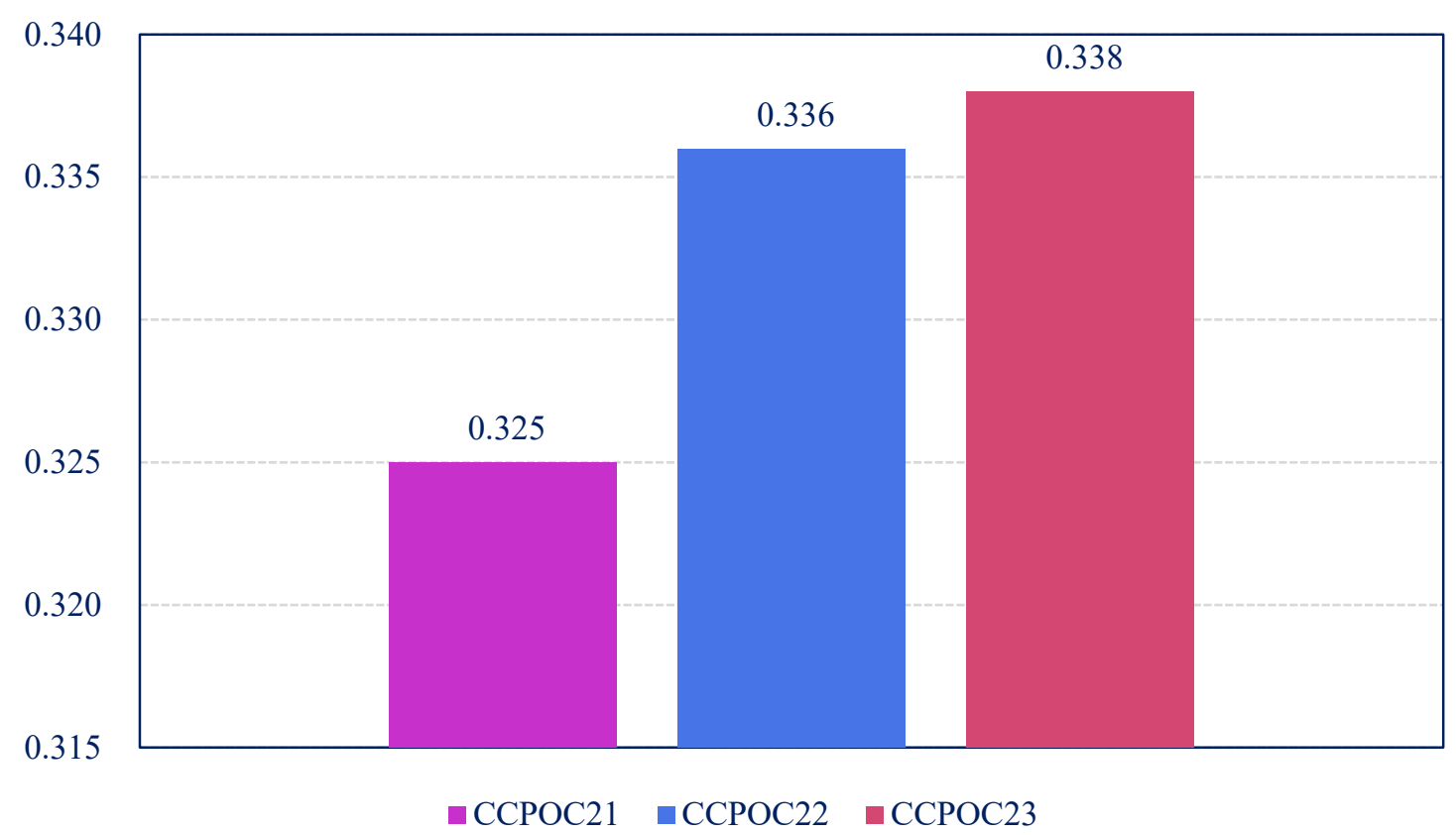

Figure 6. Ranking of the climate change policy objective sub-criteria with respect to the transport sector criteria (CCPOC2).

4.2.3. Ranking of the Sub-Criteria (CCPOSC3i's) with Respect to the Urban Planning Criteria (CCPOC3)

A fuzzy AHP analysis of the sub-criteria regarding the urban planning criteria (CCPOC3) unveiled that population and urbanization (CCPOSC31) are the most important sub-criteria (see Figure 7). Pakistan has the sixth largest population in the world with the annual average population growth rate (1998-2017) of 2.4\%. Pakistan is one of the developing economies that have higher rates of urbanization and urban sprawl. The urbanization rate during 1998-2017 was 2.7\% [17]. Rampant population growth and rural to urban migration have significant impacts on the development of the economy. However, rampant urbanization puts pressure on education and health infrastructure, urban transport, urban governance system, and environmental management. 


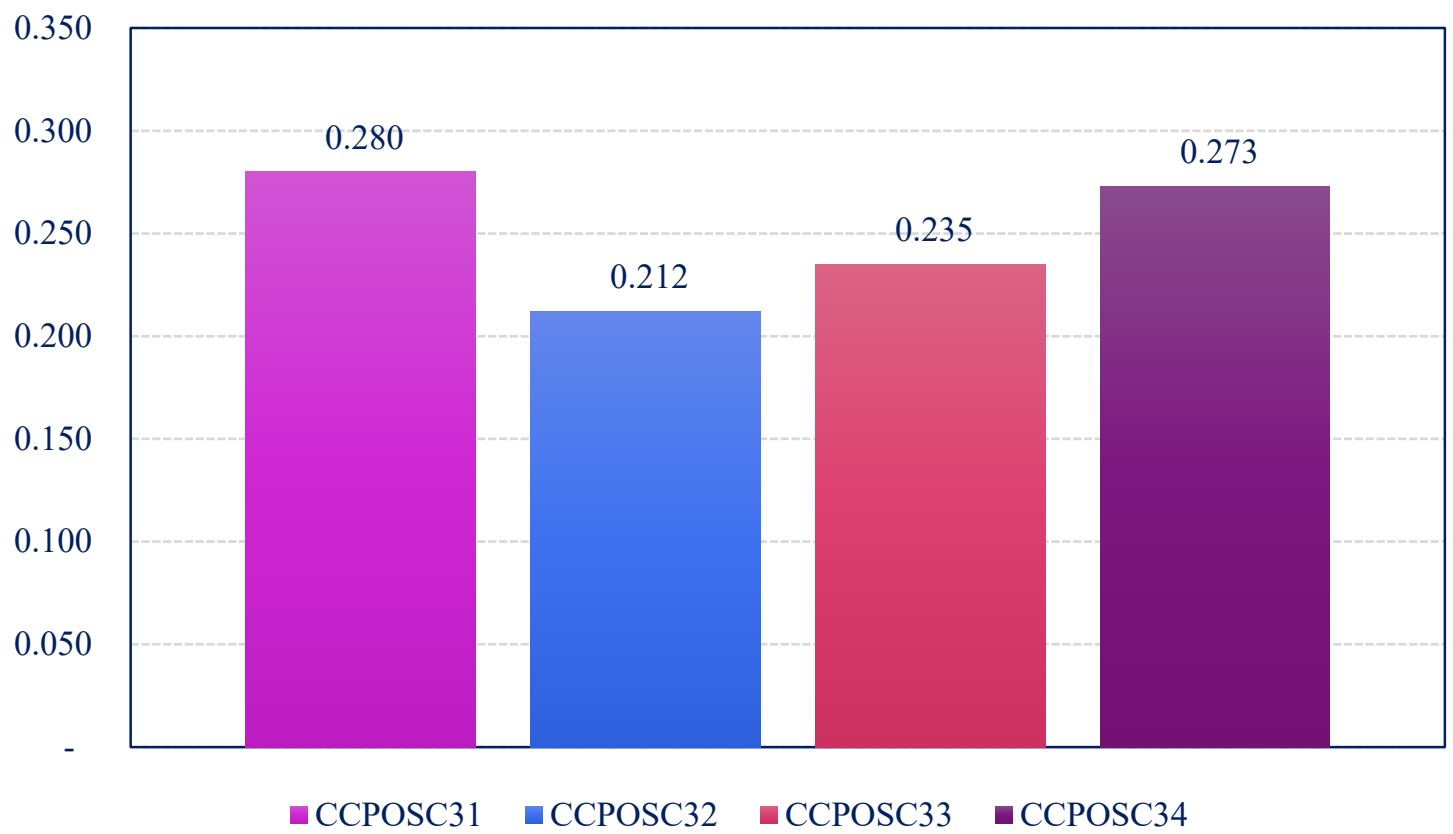

Figure 7. Ranking of the climate change policy objective sub-criteria with respect to the urban planning criteria (CСPOC3).

Water management (CCPOSC34) is ranked second as it is also an important sub-area when it comes to urban planning and development. Urban water management is one of the important areas that need attention. It refers to the natural surface water and groundwater, management of sewage and other wastewaters, and the recycling of water. It also refers to the protection of natural wetlands, waterways, and estuaries in urban and adjacent areas. Water management is of critical importance for Pakistan, especially in urban areas. It is of significant importance to execute water management plans all over the country in general but in urban areas specifically to make sure water is used efficiently [87].

Solid waste management (CCPOSC33) is ranked third in the fuzzy AHP analysis. This is also one of the challenges that urban areas are faced with. Pakistan generates about 48.5 million tons of solid waste per year and it is increasing at an alarming rate. Like other developing economies, Pakistan is lacking waste management infrastructure which is resulting in severe environmental problems. According to an estimate, about 87,000 tons of solid waste is generated per day, of which the majority is from major urban areas. The institutional capacity, bureaucratic hurdles, inadequate waste management practices, low awareness and lack of urban planning contribute to the solid waste problem (https://www.export.gov/article?id=Pakistan-Waste-Management).

The integrated mass-transit system (CCPOSC32) is ranked fourth in the sub-criteria with respect to urban planning and development. Urban transport is a major source of air and noise pollution in urban areas. In addition to these road accident injuries, traffic jams and increased commuting timings compromise the efficiency of the urban economy [24]. The development of integrated mass-transit systems in large cities contributes to the efforts of mitigation if developed through collaborative and inclusive urban planning.

\subsubsection{Ranking of the Sub-Criteria (CCPOSC4i's) with Respect to the Industry Criteria (CCPOC4)}

Ranking of the sub-criteria considering the industrial sector criteria in Figure 8 shows that air pollution is the most critical sub-criteria that needs attention. The industrial sector, combined with the energy sector, cause 51.3\% of GHG emissions in Pakistan. This contribution to GHG emissions is projected to increase to more than $64 \%$ by 2030 [17]. Pakistan is already amongst the economies that are the most vulnerable to climate change [88]. If the efforts are not made to reduce the emissions in the industrial sector, it could exacerbate the environmental vulnerability. The water pollution 
sub-criteria are ranked second with respect to industry. Rampant urbanization, along with increased industrial processes and activity, have increased the sources of water pollution. A major proportion of population in Pakistan is exposed to the hazard of drinking polluted and unsafe water. The surface water and underground water have been polluted during the last decades. This situation is getting worse and causing health problems. About $40 \%$ of all disease-related deaths are linked to water-borne diseases. Industrial effluents are one of the major sources of water pollution [89]. It is time to address water pollution issues and save freshwater reservoirs as Pakistan is already facing a water deficiency. The land pollution/brownfield management sub-criterion is ranked third in the fuzzy AHP analysis, with respect to the industry criteria. Soil pollution is a significant issue to be resolved. Industrial chemicals made during the industrial manufacturing processes are the main contributor to the land pollution problem. Land pollution management and brownfield remediation practices need to be addressed in environmental and climate change policy [29], especially in a country like Pakistan which is exposed to climate change hazards.

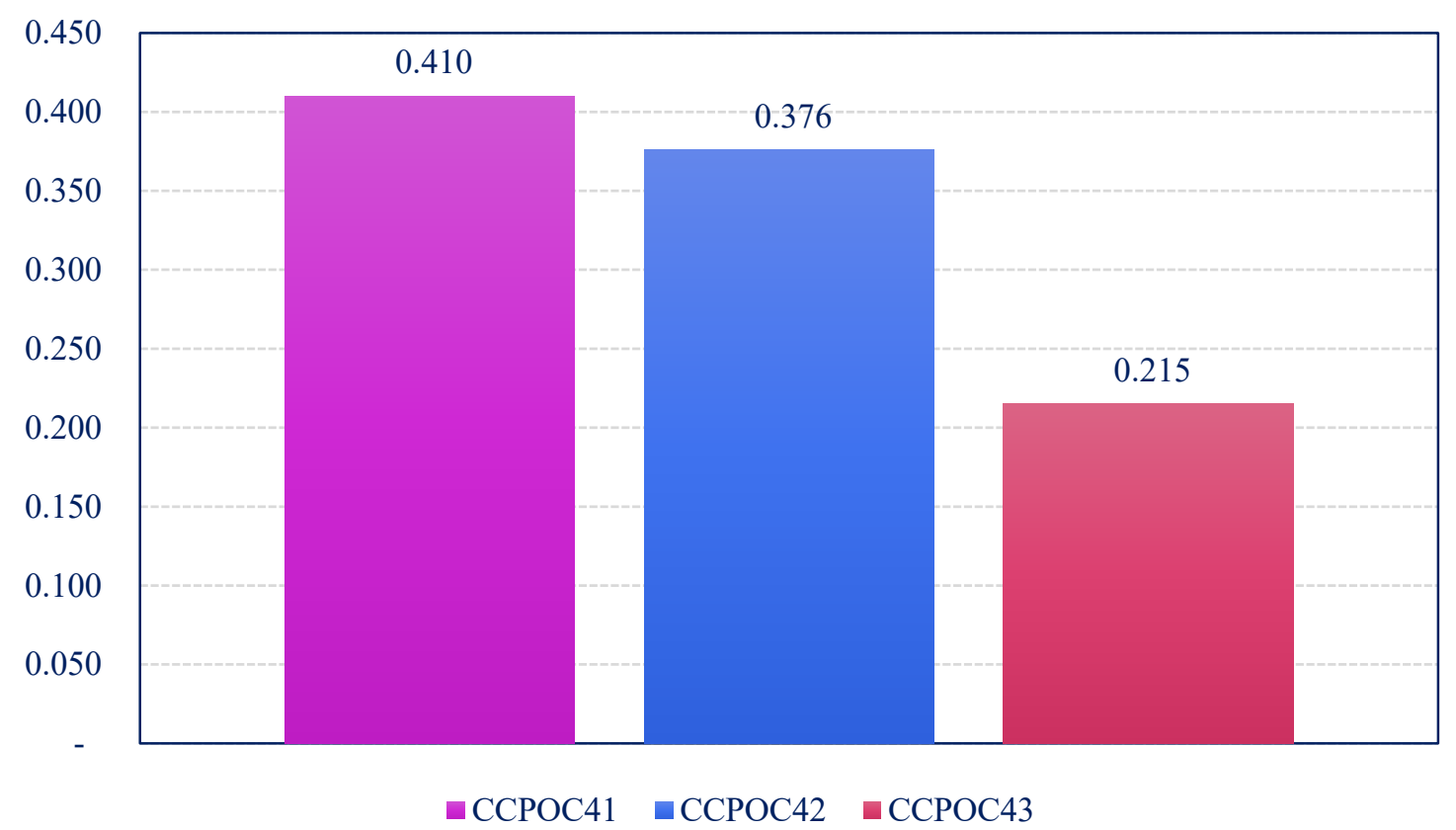

Figure 8. Ranking of the climate change policy objective sub-criteria with respect to the industry criteria (CCPOC4).

4.2.5. Ranking of the Sub-Criteria (CCPOSC5i's) with Respect to the Agriculture Sector Criteria (CCPOC5)

The representation of the ranking of the sub-criteria (CCPOSC5i's), linked to the agriculture sector criteria (CСPOC5 (in Figure 9)), shows that crop (ССРOC51) growing processes and practices are critical to consider and address to achieve the climate change policy objectives. The agriculture sector also accounts for carbon footprints. The use of fertilizers and pesticides, fuel and oil for agriculture machinery and equipment such as tractors and electric tube-wells or pumps during crop growing processes, trucking and shipping, cooling and heating, electricity for lighting, etc., are sources of carbon dioxide, methane, nitrous oxides, and the GHG gases. Pesticide exposure has caused serious health issues in Pakistan $[90,91]$. Factory farming deposits huge amounts of phosphorus, nitrogen, and other fertilizers which end up in the water. The use of fertilizers, pesticides, and herbicides also affects the land quality and natural agricultural ecosystems [92]. 


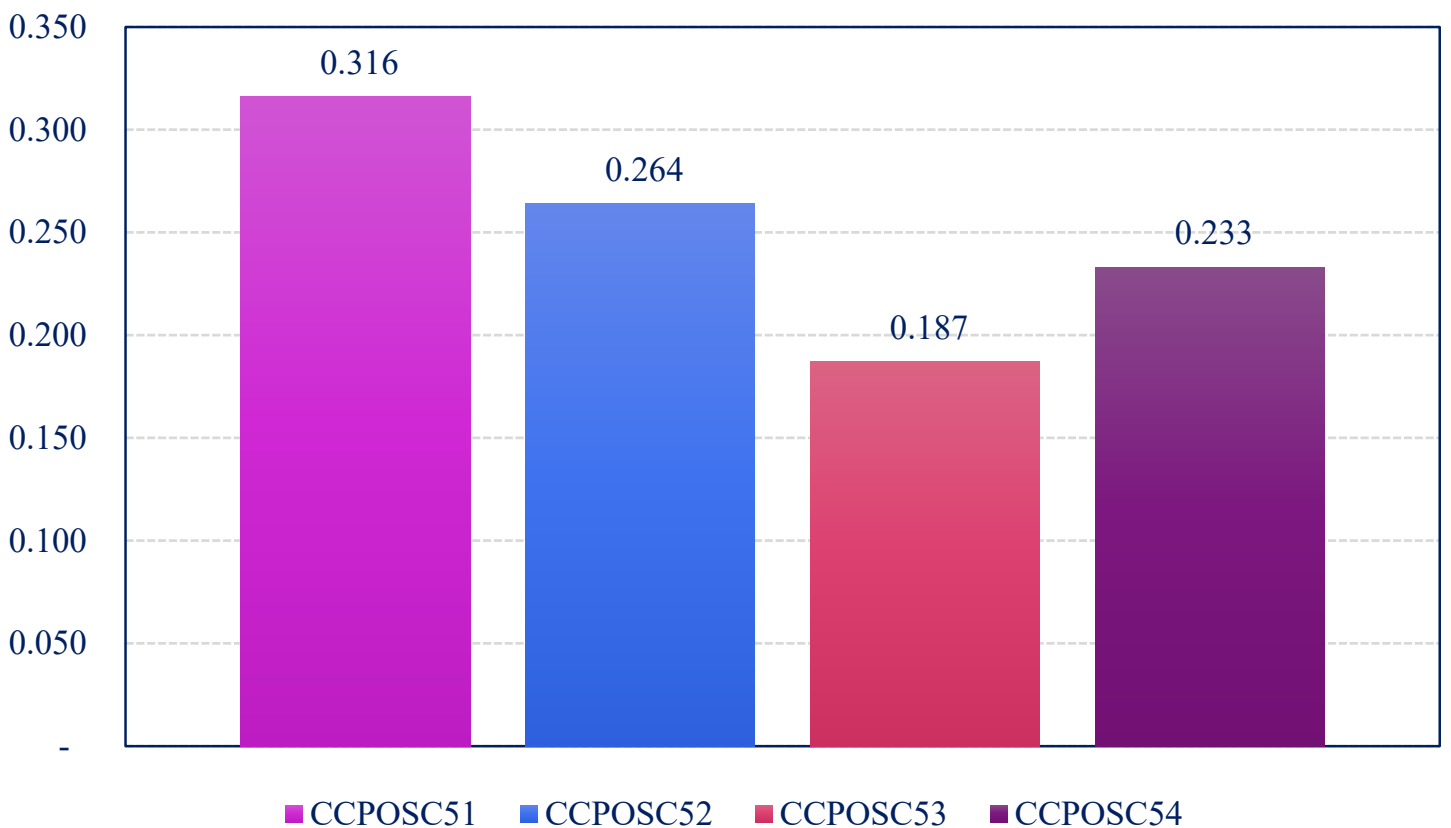

Figure 9. Ranking of the climate change policy objective sub-criteria with respect to the agriculture criteria (CCPOC5).

The irrigation system and practices sub-criteria (CCPOSC52) is ranked second in prioritization by a fuzzy AHP. The irrigation system and water use practices in agriculture in Pakistan are inefficient. Irrigation from groundwater sources is reinforcing agricultural sustainability [30,92]. Livestock (CCPOSC53), the free grazing of livestock, extended droughts, and aridity in an arid land affects the biodiversity in various areas [89]. Forestry (CCPOSC54 (ranked third)) contributes to climate change through an increased rate of deforestation [93]. Deforestation increases due to extended traditional farming methods, timber exploitation, bushfires, overgrazing, timber exploitation, and development expansion [94]. The livestock sub-criterion is ranked fourth in the fuzzy AHP analysis and is deemed to be one of the sub-sectors in agriculture affecting the environment. Despite a huge contribution of about $56 \%$ of value added to agriculture and nearly $11 \%$ to the national GDP [95], the livestock sub-sector also has implications for environmental sustainability.

\subsection{Results of the Fuzzy AHP Analysis of OVERALL CCPOSC with Respect to the Goal}

The overall ranking with respect to CCPOSC through fuzzy AHP analysis, and with respect to the goals, is represented in Figure 10. The fuzzy AHP weights of the sub-criteria reveal the prioritization of: top-ranked to low-ranked energy production (CCPOSC11), fiscal reforms in the energy sector (CCPOSC13), air pollution (CCPOSC41), water pollution (CCPOSC42), railways (CCPOSC23), general transport (CCPOSC22), road infrastructure (CCPOSC21), crops (CCPOSC51), the transmission and distribution of electricity (CCPOSC12), land pollution and brownfield management (CCPOSC43), irrigation systems and water use practices (CCPOSC52), population and urbanization (CCPOSC31), water management (CCPOSC34), forestry (CCPOSC54), solid waste management (CCPOSC33), integrated mass-transit systems (CCPOSC32), and livestock (CCPOSC53). The ranking of the sub-criteria regarding the goals of climate change and environmental policy provides a strong reason to believe that a complete and comprehensive overhauling of the energy production sector is needed in Pakistan. This sector is the major contributor to carbon emissions in Pakistan. The transport sector is one of the major contributors which intensifies the environmental conditions in Pakistan. A consistent increase in the vehicles on the road has been observed, due to the lack of a productive and efficient railway system in the country. 


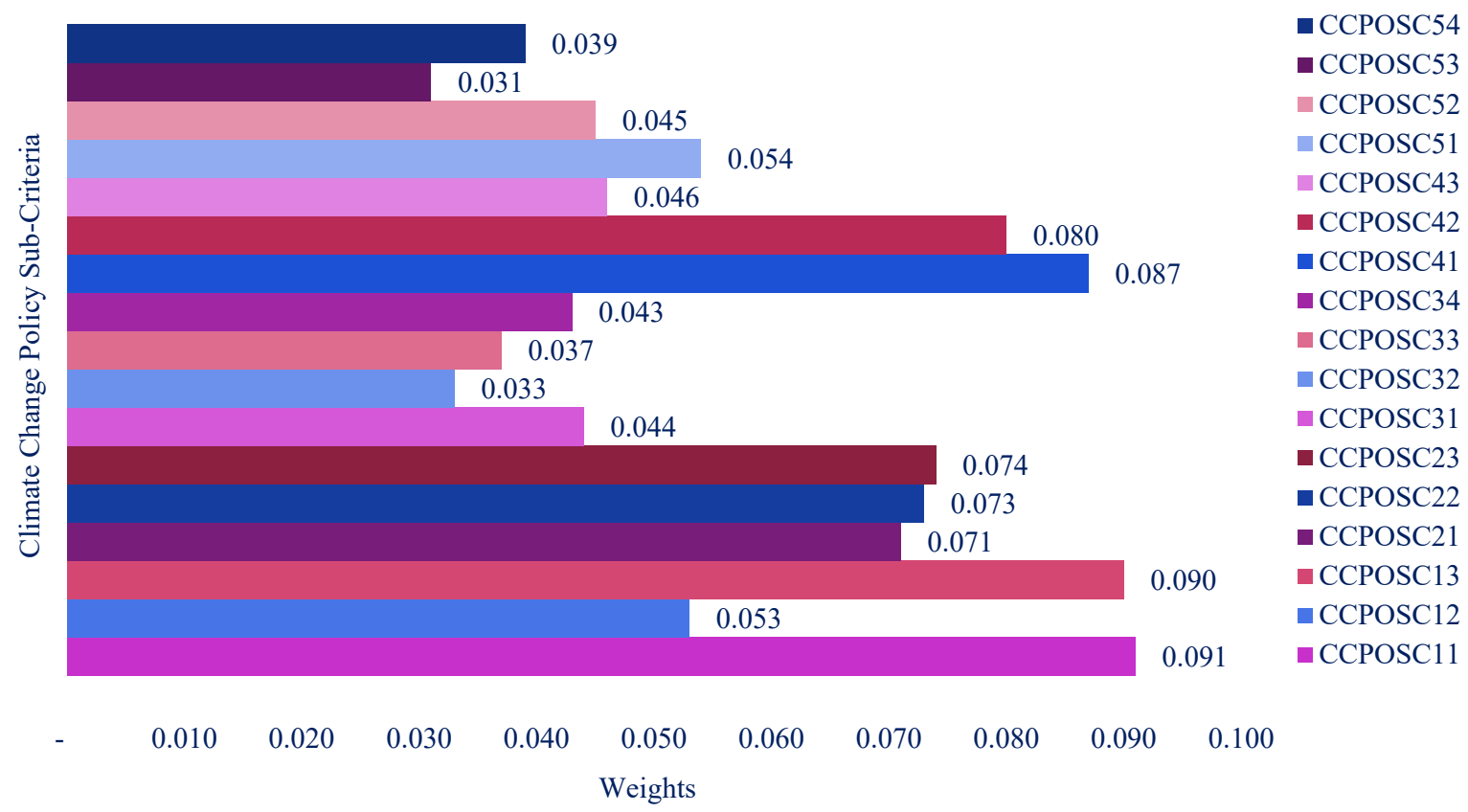

Figure 10. Ranking of the overall climate change policy objective sub-criteria with respect to the goal.

General transport in Pakistan is heavily reliant on on-road vehicles, which is one of the most oil-consuming sectors in Pakistan contributing a major share of carbon emissions. Such a heavy dependence on oil to fuel the transport system is putting a heavy toll on the environmental quality and compromising the efforts to combat climate change. Rampant population growth and rampant and unmanaged urban sprawl is another sector that is a serious threat to the climate and ecosystem. Unplanned urbanization is affecting land use as arable land is being used to accommodate urban sprawl. It is also causing a decline in green belts, forests, flora, and fauna. Issues such as air pollution, noise pollution, water pollution, solid waste management, lack of safe and pure drinking water are also related to urbanization. The industrial and manufacturing sector in Pakistan is also not environmentally friendly, as it damages the environmental quality. Inefficient irrigation systems, water management, and use practices have put the economy on the verge of a water security threat. Pakistan is one of the economies facing a water deficiency $[96,97]$.

\subsection{Results of the Fuzzy VIKOR for Climate Change Policy Objective (Alternatives)}

The results of the fuzzy VIKOR to prioritize the climate change policy objective (alternatives) given in Table 3 are represented in Figure 11. The integrated decision matrix, normalized fuzzy differences, and values of $S, R$, and $Q$ are given in Appendix C in Table A8, Table A9, and Table A10, respectively. CCPOA3, the integration of national policies, is ranked first in the fuzzy VIKOR analysis. It implies that the integration of national policies (CCPOA3) with the climate change policy and environmental policy is of fundamental importance. To be successful in fighting climate change, it is a prerequisite that climate change policy must be integrated into all levels of governance, from energy to water management, and from agriculture to traffic [48]. As climate change initiatives interact with existing policies, across-the-board support is needed if climate change issues are to be successfully tackled. An integration climate change policy (CCP) is more effective and productive as it addresses the institutions, rules, regulations and standards, social norms and preferences, political models, individual behavior, skills, and other aspects [37]. 
Table 3. Crisp values of $S, R$, and $Q$.

\begin{tabular}{ccccc}
\hline Alternative & $S_{i}$ & $\boldsymbol{R}_{\boldsymbol{i}}$ & $\boldsymbol{Q}_{\boldsymbol{i}}$ & Rank \\
\hline Institutional Capacity Building (CCPOA1) & 0.1514 & 0.0278 & 0.0241 & 2nd \\
Water Security (CCPOA2) & 0.1517 & 0.0302 & 0.0428 & 3rd \\
Integration of National Policies (CCPOA3) & 0.1881 & 0.0247 & 0.0150 & 1 st \\
Natural Disaster Management (CCPOA4) & 0.2231 & 0.0311 & 0.0790 & 5 th \\
Natural Resource Management (CCPOA5) & 0.2293 & 0.0269 & 0.0487 & 4 th \\
Social sector development and health (CCPOA6) & 0.2281 & 0.0333 & 0.0975 & 7 th \\
Environmental financial structure development (CCPOA7) & 0.3164 & 0.0278 & 0.0913 & 6th \\
\hline
\end{tabular}

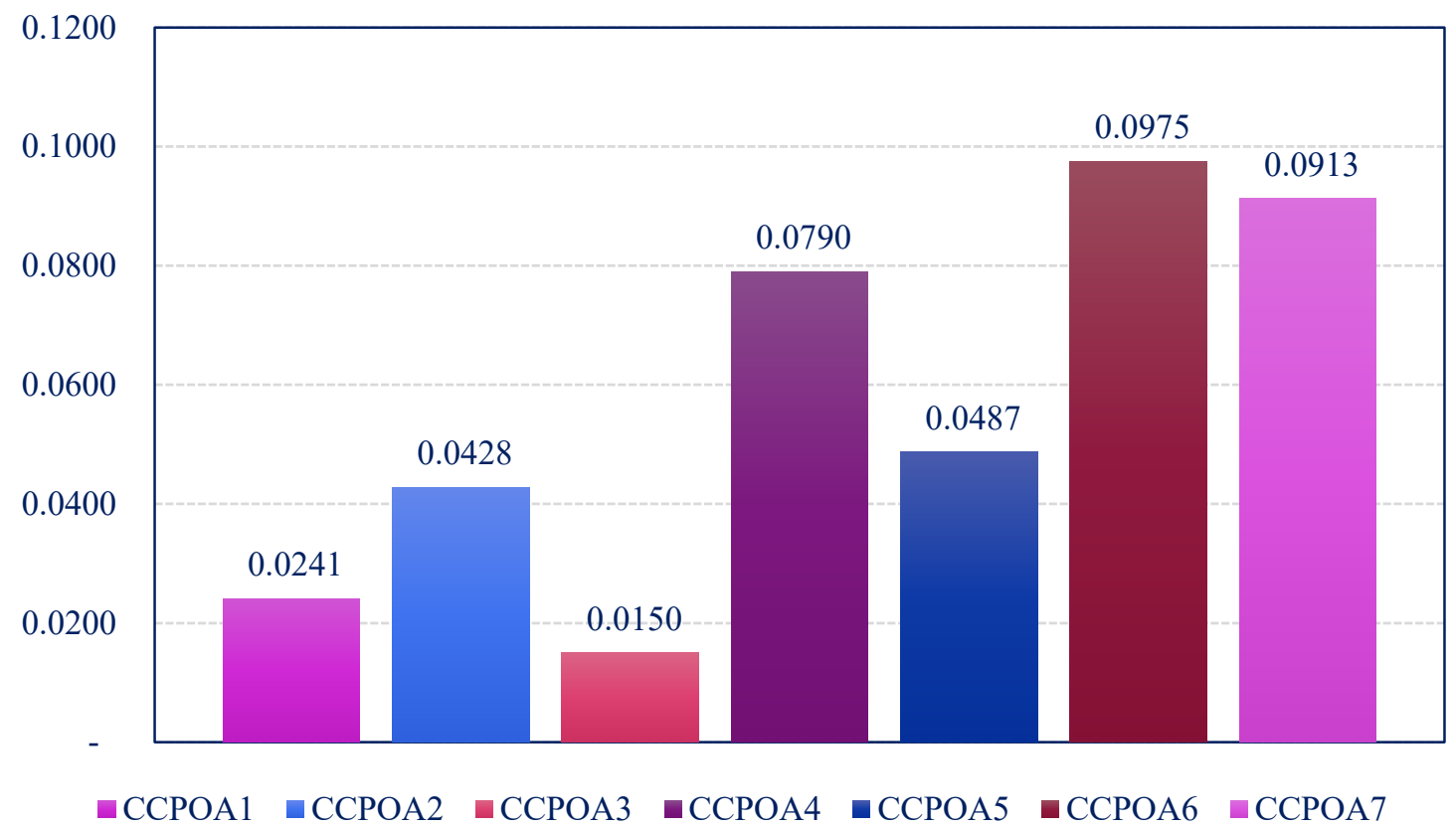

Figure 11. Final alternatives ranking according to the lowest value of $Q$.

CCPOA1 - the institutional capacity building —is ranked second, followed by water security (CCPOA2) and natural resource management (CCPOA5) ranked third and fourth, respectively. Institutional capacity building is essential for climate change mitigation and adaptation. It encompasses an economy's "human, scientific, technological, organizational, institutional, and resource capabilities". Increasing the capacity building of the government agencies, departments, and institutions would also add to the integrated national capacity and monitoring capabilities, coupled with a piece of comprehensive knowledge about the trends of the potential climate change impact on the economy [37]. Capacity building would also include the creation of a multi-hazard early warning capacity by upgrading the existing system and developing new ones to fulfill the requirements for full information and warning needs of potential vulnerability.

Water resource management is pivotal for Pakistan to fulfill the current needs [98]. A unified water resource management policy is warranted by using sophisticated and efficient irrigation technologies to save and preserve water in water abundant areas and redistribute it to fulfill the water needs in arid and semi-arid regions [36]. Further, strengthening the integrated disaster preparedness and response capacity from the local to the national level would add to the efforts of dealing with climate change. It is important to strengthen the local level risk reduction capacity by focusing on communities and creating linkages between the local, union council, tehsil, district and provincial levels to the national level. It is indispensable to enhance the capacity building of all the government institutions in general, and the National Disaster Management Authority (NDMA), specifically, from national, provincial, district to local levels. A recent study, by Grefalda et al. [99], stressed the need for local action plans to strengthen 
the local government institutions. In terms of institutional capacity building, the study required a competency development amongst the local government units as primus agencies in adaptation.

The world is showing its commitment to urgently reducing emissions to avert environmental damage and climate change. Agriculture is one of the sectors which is characterized by intensive water use. It is highly recommended by experts to reduce water consumption and increase its conservation by using high-efficiency irrigation technologies. Moreover, it is also necessary to alleviate the water shortage in arid and semi-arid areas [36]. Such efforts would add to the efforts of natural resource management. Some policy interventions in the livestock sector can make pivotal contributions to climate change efforts by offsetting some of the sector's increases. It is unlikely that this sector will be ignored as the demand for livestock is projected to increase by $70 \%$ by 2050 [32]. Currently, it is one of the major sources of emissions, contributing $14.5 \%$ of human-induced emissions. Major sources of emissions in this sector are the feed production, enteric fermentation from ruminants, manure decomposition, processing, and transportation of animal products [32].

A sizeable and significant reduction in emissions in the livestock sector is possible with wider use of already available technologies and best practices. Gerber et al. [32] proclaim that a 30\% GHG reduction is possible if the producers, in each system, region, and climate zone, adopt technologies and practices currently used by their emission-intensive peers. Policy interventions are indispensable to ensure the best practices, such as feeding practices, health management, and animal husbandry, which are possibly main interventions in reducing emissions and increasing the efficiency at the animal and herd level. In addition to this, manure management practices, such as energy recovery and recycling nutrients and energy contained in manure, energy savings, and recycling along the supply chain are the options of mitigation [32] that need to be addressed in climate change policy.

According to the fuzzy VIKOR analysis, environmental financial structure development (CCPOA7) and social sector development and health (CCPOA6) were ranked sixth and seventh, respectively. The CCP's objective cannot be achieved without establishing a climate change fund (CCF). The establishing of the Pakistan Climate Change Fund (PGCF) is indispensable in ensuring that the provision of financial resources for climate change policy objectives to achieve. There is also a need to develop a public-corporate-civil society partnership for raising finances to effectively implement climate change mitigation and adaptation projects. An efficient CCF for a CCP objective is necessary to achieve SDGs. Social sector development and health need to be integrated with the climate change policy. The promotion of equity, alleviation of poverty, reduction in inequalities, and ensuring health security are the major social sector development objectives in the SDGs [1]. A comprehensive CCP with its strict implementation would help in achieving sustainable development and the SDGs in Pakistan.

\section{Conclusion and Policy Implications}

As the global efforts to combat climate change are underway, the national governments have put forth the climate change policy action plans for mitigation and adaptation. The objectives set in the national climate change policy could be successfully achieved with appropriately prioritized policy interventions and actions. Each economy has its specific social, economic, political, technical, and institutional characteristics embedded in its governance systems with a special reference to resource endowment, the level of environmental vulnerability to climate change, and the responsive actions necessary to be taken.

It makes it important to set the climate change policy objectives and prioritize them according to the socio-economic, political, technical, financial, and governance systems in operation for a productive implementation of climate change policy. It will help to achieve the objectives set in the global climate agreement and SDGs, especially in economies like Pakistan-one of the most vulnerable economies to climate change. For this purpose, this study aimed to prioritize the climate change policy objectives in Pakistan considering the climate change policy objective criteria and the climate change policy objective sub-criteria. In doing so, the current study considered six objectives of climate change policy objectives including institutional capacity building, water security, the integration of national policies, natural 
disaster management, natural resource management, social sector development, and environmental finance structures as alternatives. The prioritization of these CCP objectives are prioritized under five criteria: energy, transport, urban and town planning, industry, and agriculture. Further, these five criteria are prioritized under 17 sub-criteria. A fuzzy AHP method was used to find the ranking of the climate change policy objective alternatives with respect to the goal.

The results revealed the energy sector to be the most important criterion to be addressed for a successful fight against climate change. The energy production was ranked first with respect to the energy criteria, due to the fact that the energy sector is a major contributor of GHG emissions. It implies that the Pakistan economy direly needs to shift its energy mix from traditional sources of energy to renewable and low-carbon energy sources. Furthermore, the fuzzy AHP results revealed that sub-criteria railways, population and urbanization, air pollution, and crops ranked first with their respective criteria with regard to transport, urban and town planning, industry, and agriculture, respectively. The overall ranking of all the sub-criteria with respect to the goal revealed that energy production is the most critical regarding climate change. Results of the fuzzy AHP analysis unfolded that the achievement of a climate change policy's objectives is heavily dependent on how the government manages energy production, transport (especially railways), population and urbanization, air pollution from the industry and transport sector, and the use of water resources in agriculture.

The fuzzy VIKOR analysis for the prioritization of CCPOAs ranked from highly preferred to less preferred as the integration of national policies, institutional capacity building, water security, natural resource management, natural disaster management, environmental financial structure development, and social sector development were introduced. This implies that the CCP should be comprehensively applied to every sector of the economy by integrating government individual policies to every sector including an energy policy, industrial policy, population and urban policy, land use policy, water management policy, policy regarding mining and quarrying and natural resource management, agriculture policy, and education policy. Further, the government should invest in the capacity building of government institutions and enhance the efficiency of these institutions.

The integration of sectoral policies with a CCP and enhanced institutional capacity building would increase the potential of the economies to mitigate and adapt to climate change through effective water management and a natural resource nanomagnet, which would increase the capability to deal with natural disaster(s). Moreover, the development of environmental financial structures, such as climate change funds, to provide the required financial resources would stimulate the efforts to mitigate and adapt to climate change. For this, government-corporate-civil society cooperation to raise funds would also be a landmark contribution. The role of non-governmental organizations cannot be neglected in this regard to provide an impetus for dealing with climate change. A collective and systematic CCP and its strict implementation would be productive in paving the way for socio-economic developments and achieve the sustainable development goals in a developing country like Pakistan.

Author Contributions: Conceptualization, W.A., Q.T., G.M.S., S.A., and Y.A.S.; methodology, Y.A.S., N.A.K. and S.A.; software, Y.A.S.; validation, Q.T., W.A. and H.W.; formal analysis, W.A. and Y.A.S.; investigation, N.A.K., H.W. and S.A.; resources, W.A., Q.T.; data curation, W.A., Q.T., and Y.A.S.; writing —original draft preparation, W.A., S.A. and Y.A.S.; writing-review and editing, H.W., G.M.S. and N.A.K.; visualization, W.A., S.A., and Y.A.S.; supervision, Q.T.; project administration, W.A., Q.T., and Y.A.S.; funding acquisition, Q.T. All authors have read and agreed to the published version of the manuscript.

Funding: This research was funded by "Fundamental Research Funds for the Central Universities", grant number NX2017001.

Acknowledgments: The authors are thankful to the experts, government officials, and the stakeholders for sparing their time and providing us the comprehensive information and their expert opinion during the research. The authors would like to thank Dr. Imran Sharif Chaudhry, Professor and Director, School of Economics, Bahauddin Zakariya University Multan, Pakistan, for constructive comments and the three anonymous reviewers for their insightful suggestions and careful reading of the manuscript.

Conflicts of Interest: The authors declare no conflict of interest. 


\section{Appendix A}

Table A1. Demographic information of the experts.

\begin{tabular}{|c|c|c|c|c|c|}
\hline Serial \# & Designation & Gender & Qualification & Age & Organization \\
\hline 1. & Professor & Male & Ph. D. & 54 & $\begin{array}{c}\text { Arid Agriculture } \\
\text { University Rawalpindi }\end{array}$ \\
\hline 2. & Professor & Male & Ph. D. & 53 & $\begin{array}{c}\text { University of Agriculture } \\
\text { Faisalabad }\end{array}$ \\
\hline 3. & Chief Economist & Male & Ph. D. & 57 & $\begin{array}{c}\text { Planning Commission of } \\
\text { Pakistan }\end{array}$ \\
\hline 4. & Additional Secretary & Male & Master & 45 & $\begin{array}{l}\text { Ministry of Climate } \\
\text { Change, Pakistan }\end{array}$ \\
\hline 5. & $\begin{array}{l}\text { Director General } \\
\text { (Environment) }\end{array}$ & Male & Master & 49 & $\begin{array}{l}\text { Ministry of Climate } \\
\text { Change, Pakistan }\end{array}$ \\
\hline 6. & Deputy Secretary & Female & Master & 42 & $\begin{array}{l}\text { Ministry of Climate } \\
\text { Change, Pakistan }\end{array}$ \\
\hline 7. & $\begin{array}{c}\text { Director (Monitoring, } \\
\text { Lab \& } \\
\text { Implementation) }\end{array}$ & Male & M. Phil. & 41 & $\begin{array}{c}\text { Environmental Protection } \\
\text { Department, Punjab, } \\
\text { Pakistan }\end{array}$ \\
\hline 8. & $\begin{array}{c}\text { Director } \\
\text { (Environmental Impact } \\
\text { Assessment) }\end{array}$ & Male & Master & 44 & $\begin{array}{c}\text { Environmental Protection } \\
\text { Department, Punjab, } \\
\text { Pakistan }\end{array}$ \\
\hline 9. & $\begin{array}{l}\text { Director of Transport } \\
\text { Planning Unit }\end{array}$ & Male & Master & 45 & $\begin{array}{l}\text { Transport Department } \\
\text { Punjab, Pakistan }\end{array}$ \\
\hline 10. & Project Manager & Male & Ph. D. & 49 & $\begin{array}{c}\text { Kachhi Canal Project } \\
\text { Private Power \& }\end{array}$ \\
\hline 11. & Managing Director & Male & Ph. D. & 51 & $\begin{array}{l}\text { Infrastructure Board, } \\
\text { Government of Pakistan }\end{array}$ \\
\hline 12. & Project Director & Male & Master & 45 & $\begin{array}{l}\text { National Program for } \\
\text { Improvement of } \\
\text { Watercourses in Pakistan } \\
\text { (Phase-II)-The Punjab } \\
\text { Component }\end{array}$ \\
\hline 13. & DG Planning & Male & Ph. D. & 56 & Ministry of Railways \\
\hline 14. & Stakeholder & Male & Master & 46 & $\begin{array}{c}\text { All Pakistan Transport } \\
\text { Association }\end{array}$ \\
\hline 15. & Stakeholder & Male & BA & 41 & $\begin{array}{l}\text { Pakistan Agriculture and } \\
\text { Dairy Famers Association }\end{array}$ \\
\hline
\end{tabular}

\section{Appendix B. Fuzzy AHP Results}

Table A2. Pairwise comparison with respect to the goal.

\begin{tabular}{|c|c|c|c|c|c|}
\hline & ССРОC1 & ССРОС2 & ССРОС 3 & ССРОC4 & ССРOC5 \\
\hline ССРОC1 & $(1.000,1.000,1.000)$ & $(1.000,1.552,5.000)$ & $(1.000,4.516,7.000)$ & $(1.000,1.719,7.000)$ & $(1.000,2.372,7.000)$ \\
\hline ССРОС2 & $\begin{array}{c}(0.200 \\
0.644,1.000) \\
\end{array}$ & $(1.000,1.000,1.000)$ & $(1.000,3.322,7.000)$ & $(0.200,1.000,5.000)$ & $(1.000,2.141,7.000)$ \\
\hline ССРОС3 & $\begin{array}{c}(0.143 \\
0.221,1.000)\end{array}$ & $\begin{array}{c}(0.143, \\
0.301,1.000)\end{array}$ & $(1.000,1.000,1.000)$ & $\begin{array}{c}(0.200 \\
0.416,3.000)\end{array}$ & $\begin{array}{c}(0.200 \\
0.518,3.000)\end{array}$ \\
\hline ССРОС4 & $\begin{array}{c}(0.143 \\
0.582,1.000)\end{array}$ & $(0.200,1.000,5.000)$ & $(0.333,2.404,5.000)$ & $(1.000,1.000,1.000)$ & $(1.000,2.141,7.000)$ \\
\hline ССРОС5 & $\begin{array}{c}(0.143 \\
0.422,1.000)\end{array}$ & $\begin{array}{c}(0.143 \\
0.467,1.000)\end{array}$ & $(0.333,1.931,5.000)$ & $\begin{array}{c}(0.143 \\
0.467,1.000)\end{array}$ & $(1.000,1.000,1.000)$ \\
\hline
\end{tabular}


Table A3. Pairwise comparison with respect to energy.

\begin{tabular}{cccc}
\hline & CCPOC11 & CCPOC12 & CCPOC13 \\
\hline CCPOC11 & $(1.000,1.000,1.000)$ & $(1.000,3.625,7.000)$ & $(0.200,1.000,5.000)$ \\
\hline CCPOC12 & $(0.143,0.276,1.000)$ & $(1.000,1.000,1.000)$ & $(0.143,0.301,1.000)$ \\
\hline CCPOC13 & $(0.200,1.000,5.000)$ & $(1.000,3.322,6.993)$ & $(1.000,1.000,1.000)$ \\
\hline
\end{tabular}

Table A4. Pairwise comparison with respect to transport.

\begin{tabular}{cccc}
\hline & CCPOC21 & CCPOC22 & CCPOC23 \\
\hline CСРOC21 & $(1.000,1.000,1.000)$ & $(0.143,0.725,5.000)$ & $(0.143,0.645,7.000)$ \\
\hline CСРOC22 & $(0.200,1.379,6.993)$ & $(1.000,1.000,1.000)$ & $(0.200,1.000,5.000)$ \\
\hline CСPOC23 & $(0.143,1.550,6.993)$ & $(0.200,1.000,5.000)$ & $(1.000,1.000,1.000)$ \\
\hline
\end{tabular}

Table A5. Pairwise comparison with respect to urban planning.

\begin{tabular}{ccccc}
\hline & CCPOC31 & CCPOC32 & CCPOC33 & CCPOC34 \\
\hline CСРОC31 & $(1.000,1.000,1.000)$ & $(1.000,2.955,7.000)$ & $(1.000,2.408,5.000)$ & $(1.000,1.000,3.000)$ \\
\hline CСРОC32 & $(0.143,0.338,1.000)$ & $(1.000,1.000,1.000)$ & $(0.200,0.645,3.000)$ & $(0.143,0.375,3.000)$ \\
\hline CСРOC33 & $(0.200,0.415,1.000)$ & $(0.333,1.550,5.000)$ & $(1.000,1.000,1.000)$ & $(0.200,0.518,3.000)$ \\
\hline CСРOC34 & $(0.333,1.000,1.000)$ & $(0.333,2.667,6.993)$ & $(0.333,1.931,5.000)$ & $(1.000,1.000,1.000)$ \\
\hline
\end{tabular}

Table A6. Pairwise comparison with respect to industry.

\begin{tabular}{cccc}
\hline & CCPOC41 & CCPOC42 & CCPOC43 \\
\hline CСРOC41 & $(1.000,1.000,1.000)$ & $(1.000,1.246,5.000)$ & $(1.000,2.955,7.000)$ \\
\hline CСРOC42 & $(0.200,0.803,1.000)$ & $(1.000,1.000,1.000)$ & $(1.000,2.141,7.000)$ \\
\hline CСPOC43 & $(0.143,0.338,1.000)$ & $(0.143,0.467,1.000)$ & $(1.000,1.000,1.000)$ \\
\hline
\end{tabular}

Table A7. Pairwise comparison with respect to agriculture.

\begin{tabular}{ccccc}
\hline & CCPOC51 & CCPOC52 & CCPOC53 & CCPOC54 \\
\hline CCPOC51 & $(1.000,1.000,1.000)$ & $(1.000,1.552,5.000)$ & $(1.000,4.077,7.000)$ & $(1.000,2.408,5.000)$ \\
\hline CCPOC52 & $(0.200,0.644,1.000)$ & $(1.000,1.000,1.000)$ & $(1.000,1.933,5.000)$ & $(1.000,1.246,5.000)$ \\
\hline CCPOC53 & $(0.143,0.245,1.000)$ & $(0.200,0.517,1.000)$ & $(1.000,1.000,1.000)$ & $(0.200,0.518,3.000)$ \\
\hline CCPOC54 & $(0.200,0.415,1.000)$ & $(0.200,0.803,1.000)$ & $(0.333,1.931,5.000)$ & $(1.000,1.000,1.000)$ \\
\hline
\end{tabular}




\section{Appendix C. Fuzzy VIKOR Results}

Table A8. Integrated decision matrix.

\begin{tabular}{|c|c|c|c|c|c|c|c|c|c|c|c|c|c|c|c|c|c|}
\hline & ССРОС11 & СCPOC12 & ССРОС13 & ССРОС21 & ССРОC22 & ССРОС23 & ССРОС31 & ССРОС32 & ССРОС33 & ССРОС34 & ССРОС41 & ССРОС42 & ССРОС43 & ССРОС51 & ССРОС52 & ССРОС53 & CCPOC54 \\
\hline A1 & $(1.8,3,4.2)$ & $(3.2,4.4,5.6)$ & $(2.6,3.8,5)$ & $(0.8,1.9,3)$ & $(1.2,2.4,3.6)$ & $(2,3.2,4.4)$ & $(1.6,2.7,3.8)$ & $(1.8,3,4.2)$ & $(1.8,3,4.2)$ & $(2.2,3.2,4.2)$ & $(1.6,2.7,3.8)$ & $(1.6,2.7,3.8)$ & $(2.4,3.5,4.6)$ & $(2.6,3.8,5)$ & $(4,5.3,6.6)$ & $(2,3.2,4.4)$ & $(3.4,4.7,6)$ \\
\hline A2 & $(1.6,2.7,3.8)$ & $(3.4,4.7,6)$ & $(2.6,3.8,5)$ & $(3.2,4.4,5.6)$ & $(0.8,1.9,3)$ & $(2.6,3.8,5)$ & $(1,2.2,3.4)$ & $(2.6,3.8,5)$ & $(1.8,2.9,4)$ & $(2,3.2,4.4)$ & $(2,3.2,4.4)$ & $(1.4,2.5,3.6)$ & $(1.8,3,4.2)$ & $(2.4,3.5,4.6)$ & $(3.2,4.4,5.6)$ & $(2.6,3.8,5)$ & $(1.2,2.4,3.6)$ \\
\hline A3 & $(2.8,4.1,5.4)$ & $(2.8,4.1,5.4)$ & $(1.8,3,4.2)$ & $(2.4,3.5,4.6)$ & $(1.2,2.4,3.6)$ & $(1.8,2.9,4)$ & $(1.4,2.5,3.6)$ & $(2.6,3.8,5)$ & $(1.6,2.7,3.8)$ & $(2.8,4.1,5.4)$ & $(3,4.1,5.2)$ & $(1.6,2.7,3.8)$ & $(2.6,3.8,5)$ & $(2,3.2,4.4)$ & $(3.4,4.7,6)$ & $(2.6,3.8,5)$ & $(2.6,3.8,5)$ \\
\hline A4 & $(2.4,3.5,4.6)$ & $(1.8,3,4.2)$ & $(2.8,4.1,5.4)$ & $(2.2,3.5,4.8)$ & $(1.2,2.4,3.6)$ & $(2.6,3.8,5)$ & $(2.6,3.8,5)$ & $(1.6,2.7,3.8)$ & $(2.4,3.5,4.6)$ & $(4,5.3,6.6)$ & $(2.4,3.5,4.6)$ & $(3.4,4.7,6)$ & $(4.6,5.9,7.2)$ & $(2.6,3.8,5)$ & $(2.6,3.8,5)$ & $(1,2.2,3.4)$ & $(2.4,3.4,4.4)$ \\
\hline A5 & $(2.4,3.5,4.6)$ & $(2.6,3.7,4.8)$ & $(3.2,4.4,5.6)$ & $(2.4,3.5,4.6)$ & $(2,3.2,4.4)$ & $(1.8,3,4.2)$ & $(1.8,3,4.2)$ & $(1.4,2.5,3.6)$ & $(2.6,3.8,5)$ & $(2.8,4.1,5.4)$ & $(3.2,4.4,5.6)$ & $(2.6,3.7,4.8)$ & $(4,5.3,6.6)$ & $(2,3.2,4.4)$ & $(3.6,5,6.4)$ & $(2,3.2,4.4)$ & $(1.8,3,4.2)$ \\
\hline A6 & $(1.8,2.8,3.8)$ & $(2,3.2,4.4)$ & $(2,3.3,4.6)$ & $(1,2.1,3.2)$ & $(2,3.2,4.4)$ & $(4,5.4,6.8)$ & $(2.4,3.5,4.6)$ & $(2.2,3.3,4.4)$ & $(1.6,2.7,3.8)$ & $(3.8,5,6.2)$ & $(2.2,3.5,4.8)$ & $(4.4,5.6,6.8)$ & $(3.8,5,6.2)$ & $(2.4,3.5,4.6)$ & $(1.8,3,4.2)$ & $(2.4,3.6,4.8)$ & $(3.2,4.4,5.6)$ \\
\hline A7 & $(3.6,5,6.4)$ & $(3.4,4.7,6)$ & $(3.4,4.7,6)$ & $(2.6,3.8,5)$ & $(1.4,2.6,3.8)$ & $(2.6,3.8,5)$ & $(3.2,4.4,5.6)$ & $(1.6,2.7,3.8)$ & $(2.6,3.8,5)$ & $(3.4,4.7,6)$ & $(1.8,3,4.2)$ & $(3.2,4.4,5.6)$ & $(2.8,4.1,5.4)$ & $(3.6,5,6.4)$ & $(3.4,4.7,6)$ & $(2.4,3.5,4.6)$ & $(3.4,4.7,6)$ \\
\hline
\end{tabular}

Table A9. Normalized fuzzy differences.

\begin{tabular}{|c|c|c|c|c|c|c|c|c|c|c|c|c|c|c|c|c|c|}
\hline & CCPOC11 & CCPOC12 & СCPOC13 & CCPOC21 & CCPOC22 & ССРОС23 & ССРОС31 & ССРОС32 & ССРОС 33 & ССРОС34 & CCPOC41 & ССРОС42 & CCPOC43 & ССРОС51 & ССРОС52 & ССРОС53 & ССРОС54 \\
\hline A1 & $\begin{array}{c}-0.417, \\
0.063,0.542 \\
\end{array}$ & $\begin{array}{c}-0.238, \\
0.333,0.905 \\
\end{array}$ & $\begin{array}{c}-0.381,0.190, \\
0.762\end{array}$ & $\begin{array}{l}-0.423, \\
0,0.423\end{array}$ & $\begin{array}{c}-0.500, \\
0.139,0.778 \\
\end{array}$ & $\begin{array}{c}-0.400, \\
0.060,0.520\end{array}$ & $\begin{array}{c}-0.391, \\
0.109,0.609 \\
\end{array}$ & $\begin{array}{c}-0.500, \\
0.139,0.778 \\
\end{array}$ & $\begin{array}{c}-0.588, \\
0.088,0.765 \\
\end{array}$ & $\begin{array}{l}-0.435, \\
0,0.478\end{array}$ & $\begin{array}{c}-0.500, \\
0.075,0.650 \\
\end{array}$ & $\begin{array}{c}-0.360, \\
0.100,0.560\end{array}$ & $\begin{array}{c}-0.154, \\
0.269,0.692\end{array}$ & $\begin{array}{c}-0.409, \\
0.136,0.682 \\
\end{array}$ & $0.040,0.520,1$ & $\begin{array}{c}-0.350, \\
0.250,0.850 \\
\end{array}$ & $\begin{array}{l}-0.042, \\
0.479,1\end{array}$ \\
\hline A2 & $\begin{array}{l}-0.458, \\
0,0.458\end{array}$ & $\begin{array}{l}-0.190, \\
0.405,1\end{array}$ & $\begin{array}{c}-0.381, \\
0.190,0.762 \\
\end{array}$ & $\begin{array}{c}0.038, \\
0.481,0.923 \\
\end{array}$ & $\begin{array}{l}-0.611, \\
0,0.611\end{array}$ & $\begin{array}{c}-0.280, \\
0.180,0.640\end{array}$ & $\begin{array}{l}-0.522, \\
0,0.522\end{array}$ & $\begin{array}{l}-0.278, \\
0.361,1\end{array}$ & $\begin{array}{c}-0.588, \\
0.059,0.706\end{array}$ & $\begin{array}{l}-0.478, \\
0,0.522\end{array}$ & $\begin{array}{c}-0.400, \\
0.200,0.800\end{array}$ & $\begin{array}{c}-0.400, \\
0.060,0.520\end{array}$ & $\begin{array}{c}-0.269 \\
0.173,0.615\end{array}$ & $\begin{array}{c}-0.455, \\
0.068,0.591\end{array}$ & $\begin{array}{c}-0.120, \\
0.340,0.800\end{array}$ & $\begin{array}{l}-0.200, \\
0.400,1\end{array}$ & $\begin{array}{l}-0.500, \\
0,0.500\end{array}$ \\
\hline A3 & $\begin{array}{c}-0.208 \\
0.292,0.792\end{array}$ & $\begin{array}{c}-0.333, \\
0.262,0.857\end{array}$ & $\begin{array}{l}-0.571, \\
0,0.571\end{array}$ & $\begin{array}{c}-0.115, \\
0.308,0.731\end{array}$ & $\begin{array}{c}-0.500, \\
0.139,0.778\end{array}$ & $\begin{array}{l}-0.440, \\
0,0.440\end{array}$ & $\begin{array}{c}-0.435, \\
0.065,0.565\end{array}$ & $\begin{array}{c}-0.444, \\
0.194,0.833\end{array}$ & $\begin{array}{l}-0.647, \\
0,0.647\end{array}$ & $\begin{array}{l}-0.478, \\
0,0.522\end{array}$ & $\begin{array}{l}-0.150, \\
0.425,1\end{array}$ & $\begin{array}{c}-0.400, \\
0.060,0.520\end{array}$ & $\begin{array}{c}-0.115, \\
0.327,0.769\end{array}$ & $\begin{array}{l}-0.545, \\
0,0.545\end{array}$ & $\begin{array}{c}-0.080, \\
0.400,0.880\end{array}$ & $\begin{array}{l}-0.200, \\
0.400,1\end{array}$ & $\begin{array}{c}-0.208, \\
0.292,0.792\end{array}$ \\
\hline A4 & $\begin{array}{c}-0.292, \\
0.167,0.625\end{array}$ & $\begin{array}{l}-0.571, \\
0,0,571\end{array}$ & $\begin{array}{c}-0.333, \\
0.262,0.857\end{array}$ & $\begin{array}{c}-0.154, \\
0.308,0.769\end{array}$ & $\begin{array}{c}-0.500, \\
0.139,0.778\end{array}$ & $\begin{array}{c}-0.280, \\
0.180,0.640\end{array}$ & $\begin{array}{c}-0.174, \\
0.348,0.870\end{array}$ & $\begin{array}{c}-0.556, \\
0.056,0.667\end{array}$ & $\begin{array}{c}-0.412, \\
0.235,0.882\end{array}$ & $\begin{array}{l}-0.043, \\
0.457,1\end{array}$ & $\begin{array}{c}-0.500, \\
0.075,0.650\end{array}$ & $0,0.500,1$ & $0.115,0.558,1$ & $\begin{array}{c}-0.409, \\
0.136,0.682\end{array}$ & $\begin{array}{c}-0.240, \\
0.220,0.680\end{array}$ & $\begin{array}{l}-0.600, \\
0,0.600\end{array}$ & $\begin{array}{r}-0.250, \\
0.208,0.667\end{array}$ \\
\hline A5 & $\begin{array}{c}-0.292, \\
0.167,0.625\end{array}$ & $\begin{array}{c}-0.381, \\
0.167,0.714\end{array}$ & $\begin{array}{c}-0.238, \\
0.333,0.905\end{array}$ & $\begin{array}{c}-0.115, \\
0.308,0.731\end{array}$ & $\begin{array}{l}-0.278, \\
0.361,1\end{array}$ & $\begin{array}{c}-0.440, \\
0.020,0.480\end{array}$ & $\begin{array}{c}-0.348, \\
0.174,0.696\end{array}$ & $\begin{array}{l}-0.611, \\
0,0.611\end{array}$ & $\begin{array}{l}-0.353, \\
0.324,1\end{array}$ & $\begin{array}{c}-0.304, \\
0.196,0.739\end{array}$ & $\begin{array}{c}-0.400, \\
0.200,0.800\end{array}$ & $\begin{array}{l}-0.480, \\
0,0.480\end{array}$ & $\begin{array}{l}-0.423, \\
0,0.423\end{array}$ & $\begin{array}{l}-0.545, \\
0,0.545\end{array}$ & $\begin{array}{l}-0.440, \\
0,0.440\end{array}$ & $\begin{array}{c}-0.350, \\
0.250,0.850\end{array}$ & $\begin{array}{c}-0.375, \\
0.125,0.625\end{array}$ \\
\hline A6 & $\begin{array}{c}-0.417 \\
0.021,0.458\end{array}$ & $\begin{array}{c}-0.524, \\
0.048,0.619\end{array}$ & $\begin{array}{c}-0.524, \\
0.071,0.667\end{array}$ & $\begin{array}{c}-0.385, \\
0.038,0.462\end{array}$ & $\begin{array}{l}-0.278, \\
0.361,1\end{array}$ & $0,0.500,1$ & $\begin{array}{c}-0.217 \\
0.283,0.783\end{array}$ & $\begin{array}{c}-0.389, \\
0.222,0.833\end{array}$ & $\begin{array}{l}-0.647, \\
0,0,647\end{array}$ & $\begin{array}{c}-0.087 \\
0.391,0.913\end{array}$ & $\begin{array}{c}-0.350, \\
0.275,0.900\end{array}$ & $\begin{array}{c}-0.160, \\
0.320,0.800\end{array}$ & $0.115,0.558,1$ & $\begin{array}{c}-0.455, \\
0.068,0.591\end{array}$ & $\begin{array}{c}-0.400, \\
0.060,0.520\end{array}$ & $\begin{array}{c}-0.250, \\
0.350,0.950\end{array}$ & $\begin{array}{c}-0.083, \\
0.417,0.917\end{array}$ \\
\hline A7 & $\begin{array}{l}-0.042, \\
0.479,1\end{array}$ & $\begin{array}{l}-0.190, \\
0.405,1\end{array}$ & $\begin{array}{l}-0.190, \\
0.405,1\end{array}$ & $0.077,0.538,1$ & $\begin{array}{c}-0.444, \\
0.194,0.833\end{array}$ & $\begin{array}{c}-0.120 \\
0.360,0.840\end{array}$ & $\begin{array}{l}-0.043, \\
0.478,1\end{array}$ & $\begin{array}{c}-0.389 \\
0.278,0.944\end{array}$ & $\begin{array}{l}-0.353, \\
0.324,1\end{array}$ & $\begin{array}{c}-0.174 \\
0.326,0.870\end{array}$ & $\begin{array}{l}-0.600, \\
0,0.600\end{array}$ & $\begin{array}{c}-0.040, \\
0.440,0.920\end{array}$ & $\begin{array}{c}-0.077 \\
0.385,0.846\end{array}$ & $\begin{array}{l}-0.182, \\
0.409,1\end{array}$ & $\begin{array}{c}-0.080 \\
0.400,0.880\end{array}$ & $\begin{array}{c}-0.250 \\
0.325,0.900\end{array}$ & $\begin{array}{l}-0.042, \\
0.479,1\end{array}$ \\
\hline
\end{tabular}


Table A10. Values of S, R and Q.

\begin{tabular}{cccccccccc}
\hline \multicolumn{2}{c}{ Alternative } & \multicolumn{2}{c}{ Si } & & \multicolumn{3}{c}{$\mathbf{R i}$} & \multicolumn{3}{c}{ Qi } \\
\hline A1 & -0.3715 & 0.1505 & 0.6750 & -0.0024 & 0.0278 & 0.0580 & -0.8892 & 0.0352 & 0.9264 \\
\hline A2 & -0.3718 & 0.1508 & 0.6760 & 0.0024 & 0.0302 & 0.0580 & -0.8523 & 0.0538 & 0.9268 \\
\hline A3 & -0.3381 & 0.1873 & 0.7152 & -0.0073 & 0.0232 & 0.0580 & -0.9127 & 0.0150 & 0.9427 \\
\hline A4 & -0.3035 & 0.2222 & 0.7505 & 0.0043 & 0.0311 & 0.0580 & -0.8101 & 0.0901 & 0.9572 \\
\hline A5 & -0.2980 & 0.2285 & 0.7574 & -0.0021 & 0.0247 & 0.0580 & -0.8572 & 0.0433 & 0.9600 \\
\hline A6 & -0.2965 & 0.2272 & 0.7536 & 0.0086 & 0.0333 & 0.0580 & -0.7744 & 0.1086 & 0.9584 \\
\hline A7 & -0.2221 & 0.3155 & 0.8557 & -0.0024 & 0.0278 & 0.0580 & -0.8284 & 0.1024 & 1.0000 \\
\hline
\end{tabular}

\section{References}

1. Markkanen, S.; Anger-kraavi, A. Social impacts of climate change mitigation policies and their implications for inequality. Clim. Policy 2019, 19, 1-18. [CrossRef]

2. Gomez-Echeverri, L. Climate and development: Enhancing impact through stronger linkages in the implementation of the Paris Agreement and the Sustainable Development Goals (SDGs). Philos. Trans. R. Soc. A Math. Phys. Eng. Sci. 2018, 376, 20160444. [CrossRef] [PubMed]

3. Tobin, P.; Schmidt, N.M.; Tosun, J.; Burns, C. Mapping states' Paris climate pledges: Analysing targets and groups at COP 21. Glob. Environ. Chang. 2018, 48, 11-21. [CrossRef]

4. Popoola, O.O.; Yusuf, S.F.G.; Monde, N. South African National Climate Change Response Policy Sensitization: An Assessment of Smallholder Farmers in Amathole District Municipality, Eastern Cape Province. Sustainability 2020, 12, 2616. [CrossRef]

5. UNFCCC. The Paris Agreement; United Nations Framework Convention on Climate Change (UNFCCC): Paris, French, 2015.

6. MOF. Pakistan Economic Survey 2019-2020; Ministry of Finance (MOF), Government of Pakistan: Islamabad, Pakistan, 2020.

7. USAID Food Assistance Fact Sheet-Pakistan|Food Assistance|U.S. Agency for International Development. Available online: https://www.usaid.gov/pakistan/food-assistance (accessed on 21 June 2020).

8. Eckstein, D.; Künzel, V.; Schäfer, L.; Winges, M. Global Climate Risk Index 2020: Who Suffers Most from Extreme Weather Events? Germanwatch: Berlin, Germany, 2020; ISBN 9783943704778.

9. Parry, J.-E.; Terton, A.; Osman, H. Making Every Drop Count: Pakistan's Growing Water Scarcity Challenge. Available online: https://www.iisd.org/library/making-every-drop-count-pakistan-s-growingwater-scarcity-challenge (accessed on 20 May 2020).

10. Islam, M.S.; Kieu, E. Tackling regional climate change impacts and food security issues: A critical analysis across ASEAN, PIF, and SAARC. Sustainability 2020, 12, 883. [CrossRef]

11. MOE. National Environmental Policy 2005; Ministry of Environment (MOE), Government of Pakistan: Islamabad, Pakistan, 2005.

12. MoCC. National Climate Change Policy 2012; Ministry of Climate Change (MoCC), Government of Pakistan: Islamabad, Pakistan, 2012.

13. GOP. Pakistan Climate Change Act, 2017; Senate Secretariat: Islamabad, Pakistan, 2017.

14. Mumtaz, M. The National Climate Change Policy of Pakistan: An Evaluation of Its Impact on Institutional Change. Earth Syst. Environ. 2018, 2, 525-535. [CrossRef]

15. Shah, S.A.A.; Solangi, Y.A.; Ikram, M. Analysis of barriers to the adoption of cleaner energy technologies in Pakistan using Modified Delphi and Fuzzy Analytical Hierarchy Process. J. Clean. Prod. 2019, 235, 1037-1050. [CrossRef]

16. Solangi, Y.A.; Tan, Q.; Mirjat, N.H.; Ali, S. Evaluating the strategies for sustainable energy planning in Pakistan: An integrated SWOT-AHP and Fuzzy-TOPSIS approach. J. Clean. Prod. 2019, 236, 117655. [CrossRef]

17. MoF. Pakistan Economic Survey 2017-18; Ministry of Finance (MoF), Government of Pakistan: Islamabad, Pakistan, 2018. 
18. Ali, S.; Xu, H.; Al-amin, A.Q.; Ahmad, N. Energy sources choice and environmental sustainability disputes: An evolutional graph model approach. Qual. Quant. 2019, 53, 561-581. [CrossRef]

19. Shirwani, R.; Gulzar, S.; Asim, M.; Umair, M.; Al-Rashid, M.A. Control of vehicular emission using innovative energy solutions comprising of hydrogen for the transportation sector in Pakistan: A case study of Lahore City. Int. J. Hydrogen Energy 2019. [CrossRef]

20. Badassa, B.B.; Sun, B.; Qiao, L. Sustainable Transport Infrastructure and Economic Returns: A Bibliometric and Visualization Analysis. Sustainability 2020, 12, 2033. [CrossRef]

21. Henke, I.; Carten, A.; Molitierno, C.; Errico, A. Decision-Making in the Transport Sector: A Sustainable Evaluation Method for Road Infrastructure. Sustainability 2020, 12, 764. [CrossRef]

22. ADB. Climate Change Profile of Pakistan; Asian Development Bank: Manila, Philippines, 2017.

23. Ali, S.; Xu, H.; Ahmed, W.; Ahmad, N.; Solangi, Y.A. Metro design and heritage sustainability: Conflict analysis using attitude based on options in the graph model. Environ. Dev. Sustain. 2019. [CrossRef]

24. Ali, S.; Xu, H.; Xu, P.; Ahmed, W. Evolutional Attitude Based on Option Prioritization for Conflict Analysis of Urban Transport Planning in Pakistan. J. Syst. Sci. Syst. Eng. 2019, 28, 356-381. [CrossRef]

25. Russo, T.; Alfredo, K.; Fisher, J. Sustainable Water Management in Urban, Agricultural, and Natural Systems. Water 2014, 6, 3934-3956. [CrossRef]

26. Noreen, U.; Ahmed, Z.; Khalid, A.; Di Serafino, A.; Habiba, U.; Ali, F.; Hussain, M. Water pollution and occupational health hazards caused by the marble industries in district Mardan, Pakistan. Environ. Technol. Innov. 2019, 16, 100470. [CrossRef]

27. Azizullah, A.; Khattak, M.N.K.; Richter, P.; Häder, D.-P. Water pollution in Pakistan and its impact on public health-A review. Environ. Int. 2011, 37, 479-497. [CrossRef]

28. Mir, K.A.; Purohit, P.; Mehmood, S. Sectoral assessment of greenhouse gas emissions in Pakistan. Environ. Sci. Pollut. Res. 2017, 24, 27345-27355. [CrossRef]

29. Ahmad, N.; Zhu, Y.; Shafait, Z.; Sahibzada, U.F.; Waheed, A. Critical barriers to brownfield redevelopment in developing countries: The case of Pakistan. J. Clean. Prod. 2019, 212, 1193-1209. [CrossRef]

30. Imran, M.A.; Ali, A.; Ashfaq, M.; Hassan, S.; Culas, R.; Ma, C. Impact of climate smart agriculture (CSA) through sustainable irrigation management on Resource use efficiency: A sustainable production alternative for cotton. Land Use Policy 2019, 88, 104113. [CrossRef]

31. Cristache, S.E.; Vuţă, M.; Marin, E.; Cioacă, S.I.; Vuţă, M. Organic versus conventional farming-a paradigm for the sustainable development of the European Countries. Sustainability 2018, 10, 4279. [CrossRef]

32. Gerber, P.J.; Steinfeld, H.; Henderson, B.; Mottet, A.; Opio, C.; Dijkam, J.; Falcucci, A.; Tempio, G. Tackling Climate Change Through Livestock; Food and Agriculture Organization (FAO) of the United Nations: Rome, Italy, 2013; Volume 14.

33. Zameer, H.; Wang, Y. Energy production system optimization: Evidence from Pakistan. Renew. Sustain. Energy Rev. 2018, 82, 886-893. [CrossRef]

34. MoF. Pakistan Economic Survey (PES) 2015-16; Ministry of Finance (MoF), Government of Pakistan: Islamabad, Pakistan, 2016.

35. Zaman, A.U.; Lehmann, S. Challenges and Opportunities in Transforming a City into a "Zero Waste City". Challenges 2011, 2, 73-93. [CrossRef]

36. Li, G.; Zhou, D.; Shi, M. How Do Farmers Respond to Water Resources Management Policy in the Heihe River Basin of China? Sustainability 2019, 11, 2096. [CrossRef]

37. Somanathan, E.; Sterner, T.; Sugiyama, T.; Chimanikire, D.; Dubash, N.K.; Essandoh-Yeddu, J.; Fifita, S.; Goulder, L.; Jaffe, A.; Labandeira, X.; et al. 2014: National and Sub-national Policies and Institu- tions. In Climate Change 2014: Mitigation of Climate Change; Contribution of Working Group III to the Fifth Assessment Report of the Intergovernmental Panel on Climate Change; Cambridge University Press: Cambridge, UK; New York, NY, USA, 2014.

38. Khan, M.D.; Shakya, S.; Vu, H.H.T.; Ahn, J.W.; Nam, G. Water environment policy and climate change: A comparative study of India and South Korea. Sustainability 2019, 11, 3284. [CrossRef]

39. United Nations Water can Help Win the Race to Limit Climate Change|UN-Water. Available online: https://www.unwater.org/water-can-help-win-the-race-to-limit-climate-change/ (accessed on 19 June 2020).

40. MoF. Economic Survey of Pakistan 2018-19; Ministry of Finance (MoF), Government of Pakistan: Islamabad, Pakistan, 2019. 
41. Sleet, P. Water Resources in Pakistan: Scarce, Polluted and Poorly Governed. Available online: http://www. futuredirections.org.au/wp-content/uploads/2019/01/Pakistan-Water-Crisis.pdf (accessed on 16 July 2020).

42. GoP. National Water Policy 2018; Ministry of Water Resources, Government of Pakistan: Islamabad, Pakistan, 2018.

43. Tyler, E. Aligning South African energy and climate change mitigation policy. Clim. Policy 2010. [CrossRef]

44. CPEIR. Pakistan-Climate Public Expenditure and Institutional Review (CPEIR): Working towards a more Efficient and Effective Allocation and Use of Climate Change-Related Finance; United Nations Development Programme Pakistan: Islamabad, Islamabad, 2015.

45. GoP. National Disaster Risk Reduction Policy 2013; Government of Pakistan, Ministry of Climate Change, National Disaster Management Authority: Islamabad, Pakistan, 2013.

46. Meinzen-Dick, R. Foreword. In Redefining Diversity \& Dynamics of Natural Resources Management in Asia. Sustain. Natural Resour. Manag. Asia 2017, 1, xix-xx. [CrossRef]

47. WHO. WHO|The Social Dimensions of Climate Change; World Health Organization: Geneva, Switzerland, 2012.

48. GoP. Pakistan Climate Change Financing Framework: A Road Map to Systematically Mainstream Climate Change into Public Economic and Financial Management; United Nations Development Programme: Pakistan, Islamabad, 2017.

49. Demirel, T.; Kahraman, C. Fuzzy Analytic Hierarchy Process and Its Applications. In Fuzzy Multi-Criteria Decision Making; Kahraman, C., Ed.; Springer Science + Business Media: Boston, MA, USA, 2008.

50. Putra, M.S.D.; Andryana, S.; Gunaryati, A. Fuzzy Analytical Hierarchy Process Method to Determine the Quality of Gemstones. Adv. Fuzzy Syst. 2018, 2018, 1-6. [CrossRef]

51. Mardani, A.; Jusoh, A.; Zavadskas, E.K. Fuzzy multiple criteria decision-Making techniques and applications-Two decades review from 1994 to 2014. Expert Syst. Appl. 2015, 42, 4126-4148. [CrossRef]

52. Ziemba, P. NEAT F-PROMETHEE-A new fuzzy multiple criteria decision making method based on the adjustment of mapping trapezoidal fuzzy numbers. Expert Syst. Appl. 2018, 110, 363-380. [CrossRef]

53. Papapostolou, A.; Karakosta, C.; Apostolidis, G.; Doukas, H. An AHP-SWOT-Fuzzy TOPSIS Approach for Achieving a Cross-Border RES Cooperation. Sustainability 2020, 12, 2886. [CrossRef]

54. Salimi, A.H.; Noori, A.; Bonakdari, H.; Masoompour Samakosh, J.; Sharifi, E.; Hassanvand, M.; Gharabaghi, B.; Agharazi, M. Exploring the Role of Advertising Types on Improving the Water Consumption Behavior: An Application of Integrated Fuzzy AHP and Fuzzy VIKOR Method. Sustainability 2020, 12, 1232. [CrossRef]

55. Dao, M.; Nguyen, A.; Nguyen, T.; Pham, H.; Nguyen, D.; Tran, Q.; Dao, H.; Nguyen, D.; Dang, H.; Hens, L. A Hybrid Approach Using Fuzzy AHP-TOPSIS Assessing Environmental Conflicts in the Titan Mining Industry along Central Coast Vietnam. Appl. Sci. 2019, 9, 2930. [CrossRef]

56. Akram, M.; Al-Kenani, A.N.; Alcantud, J.C.R. Group decision-making based on the VIKOR method with trapezoidal bipolar fuzzy information. Symmetry (Basel) 2019, 11, 1-21.

57. Solangi, Y.A.; Shah, S.A.A.; Zameer, H.; Ikram, M.; Saracoglu, B.O. Assessing the solar PV power project site selection in Pakistan: Based on AHP-fuzzy VIKOR approach. Environ. Sci. Pollut. Res. 2019, 1-17. [CrossRef] [PubMed]

58. Ahmed, W.; Tan, Q.; Ali, S.; Ahmad, N. Addressing environmental implications of crop stubble burning in Pakistan: Innovation platforms as an alternative approach. Int. J. Glob. Warm. 2019, 19, 76-93. [CrossRef]

59. Wang, B.; Song, J.; Ren, J.; Li, K.; Duan, H.; Wang, X. Selecting sustainable energy conversion technologies for agricultural residues: A fuzzy AHP-VIKOR based prioritization from life cycle perspective. Resour. Conserv. Recycl. 2019, 142, 78-87. [CrossRef]

60. Busico, G.; Giuditta, E.; Kazakis, N.; Colombani, N. A Hybrid GIS and AHP Approach for Modelling Actual and Future Forest Fire Risk Under Climate Change Accounting Water Resources Attenuation Role. Sustainability 2019, 11, 7166. [CrossRef]

61. Xu, L.; Wang, Y.; Shah, S.A.A.; Zameer, H.; Solangi, Y.A.; Walasai, G.D.; Siyal, Z.A. Economic Viability and Environmental Efficiency Analysis of Hydrogen Production Processes for the Decarbonization of Energy Systems. Processes 2019, 7, 494. [CrossRef]

62. Suganthi, L. Multi expert and multi criteria evaluation of sectoral investments for sustainable development: An integrated fuzzy AHP, VIKOR/DEA methodology. Sustain. Cities Soc. 2018, 43, 144-156. [CrossRef]

63. Udie, J.; Bhattacharyya, S.; Ozawa-Meida, L. A Conceptual Framework for Vulnerability Assessment of Climate Change Impact on Critical Oil and Gas Infrastructure in the Niger Delta. Climate 2018, 6, 11. [CrossRef] 
64. Champalle, C.; Ford, J.D.; Sherman, M. Prioritizing climate change adaptations in Canadian Arctic communities. Sustainability 2015, 7, 9268-9292. [CrossRef]

65. Kim, Y.; Chung, E.S. Robust Prioritization of Climate Change Adaptation Strategies Using the VIKOR Method with Objective Weights. J. Am. Water Resour. Assoc. 2015, 51, 1167-1182. [CrossRef]

66. Chung, E.S.; Kim, Y. Development of fuzzy multi-criteria approach to prioritize locations of treated wastewater use considering climate change scenarios. J. Environ. Manag. 2014, 146, 505-516. [CrossRef] [PubMed]

67. Kim, Y.; Chung, E. Fuzzy VIKOR approach for assessing the vulnerability of the water supply to climate change and variability in South Korea. Appl. Math. Model. 2013, 37, 9419-9430. [CrossRef]

68. Kaya, T.; Kahraman, C. Multicriteria renewable energy planning using an integrated fuzzy VIKOR \& AHP methodology: The case of Istanbul. Energy 2010, 35, 2517-2527.

69. Saaty, T.L. The Analytic Hierarchy Process; McGraw-Hill: New York, NY, USA, 1980.

70. Saaty, T.L.; Kearns, K.P. Analytical Planning the Organization of Systems; Pergamon Press: Oxford, UK, 1985.

71. Zadeh, L.A. Fuzzy sets. Inf. Control 1965, 8, 338-353. [CrossRef]

72. Bellman, R.E.; Zadeh, L.A. Decision-Making in a Fuzzy Environment. Manag. Sci. 1970, 17, B-141-B-164. [CrossRef]

73. Kahraman, C.; Onar, S.Ç.; Öztaysi, B. Fuzzy decision making: Its pioneers and supportive environment. In Studies in Fuzziness and Soft Computing; Kahraman, C., Kaymak, U.Y., Azici, A., Eds.; Springer, Cham: Berlin/Heidelberg, Germany, 2016; Volume 341, pp. 21-58.

74. Methodology, F.B.; Solangi, Y.A.; Longsheng, C.; Ahsan, S.; Shah, A.; Alsanad, A. Analyzing Renewable Energy Sources of a Developing Country for Sustainable Development: An Integrated Fuzzy Based-Decision Methodology. Processes 2020, 8, 825. [CrossRef]

75. Chang, D.Y. Applications of the extent analysis method on fuzzy AHP. Eur. J. Oper. Res. 1996, 95, 649-655. [CrossRef]

76. Opricovic, S.; Tzeng, G.H. Extended VIKOR method in comparison with outranking methods. Eur. J. Oper. Res. 2007, 178, 514-529. [CrossRef]

77. Wang, C.N.; Van Thanh, N.; Chyou, J.T.; Lin, T.F.; Nguyen, T.N. Fuzzy multicriteria decision-making model (MCDM) for raw materials supplier selection in plastics industry. Mathematics 2019, 7, 981. [CrossRef]

78. Shemshadi, A.; Shirazi, H.; Toreihi, M.; Tarokh, M.J. A fuzzy VIKOR method for supplier selection based on entropy measure for objective weighting. Expert Syst. Appl. 2011, 38, 12160-12167. [CrossRef]

79. Opricovic, S.; Tzeng, G.H. Defuzzification within a multicriteria decision model. Int. J. Uncertainty Fuzziness Knowlege-Based Syst. 2003, 11, 635-652. [CrossRef]

80. Opricovic, S.; Tzeng, G.H. Multicriteria planning of post-Earthquake sustainable reconstruction. Comput. Civ. Infrastruct. Eng. 2002. [CrossRef]

81. Opricovic, S.; Tzeng, G.H. Fuzzy multicriteria model for postearthquake land-Use planning. Natural Hazards Rev. 2003, 4, 59-64. [CrossRef]

82. Opricovic, S.; Tzeng, G.H. Compromise solution by MCDM methods: A comparative analysis of VIKOR and TOPSIS. Eur. J. Oper. Res. 2004. [CrossRef]

83. Ahmed, W.; Tan, Q.; Solangi, Y.A.; Ali, S. Sustainable and Special Economic Zone Selection under Fuzzy Environment: A Case of Pakistan. Symmetry 2020, 12, 242. [CrossRef]

84. Baloch, M.H.; Tahir Chauhdary, S.; Ishak, D.; Kaloi, G.S.; Nadeem, M.H.; Wattoo, W.A.; Younas, T.; Hamid, H.T. Hybrid energy sources status of Pakistan: An optimal technical proposal to solve the power crises issues. Energy Strateg. Rev. 2019, 24, 132-153. [CrossRef]

85. Shoaib, M. Multi-year Expert Meeting on Transport, Trade Logistics and Trade Facilitation: Sustainable Freight Transport Systems: Opportunities for Developing Countries. In Proceedings of the Government of Pakistan, Ministry of Communications Country Statement on Sustainable Transport, Multi Year Expert Meeting, Geneva, Switzerland, 14-16 October 2015.

86. WDI. World Development Indicators 2019; World Bank: Washinton, DC, USA, 2019.

87. Daud, M.K.; Nafees, M.; Ali, S.; Rizwan, M.; Bajwa, R.A.; Shakoor, M.B.; Arshad, M.U.; Ali, S.; Chatha, S.; Deeba, F.; et al. Drinking Water Quality Status and Contamination in Pakistan. BioMed Res. 2017. [CrossRef]

88. Kreft, S.; Eckstein, D.; Melchior, I. Global Climate Risk Index 2017. Who Suffers Most From Extreme Weather Events? Weather-related Loss Events in 2015 and 1996 to 2015; Germanwatch: Bonn, Germany, 2017; pp. 1-32.

89. MoF. Pakistan Economic Survey 2016-17; Ministry of Finance (MoF), Government of Pakistan: Islamabad, Pakistan, 2017. 
90. Memon, Q.U.A.; Wagan, S.A.; Chunyu, D.; Shuangxi, X.; Jingdong, L.; Damalas, C.A. Health problems from pesticide exposure and personal protective measures among women cotton workers in southern Pakistan. Sci. Total Environ. 2019, 685, 659-666. [CrossRef]

91. Saeed, M.F.; Shaheen, M.; Ahmad, I.; Zakir, A.; Nadeem, M.; Chishti, A.A.; Shahid, M.; Bakhsh, K.; Damalas, C.A. Pesticide exposure in the local community of Vehari District in Pakistan: An assessment of knowledge and residues in human blood. Sci. Total Environ. 2017, 587-588, 137-144. [CrossRef] [PubMed]

92. Zulfiqar, F.; Thapa, G.B. Agricultural sustainability assessment at provincial level in Pakistan. Land Use Policy 2017, 68, 492-502. [CrossRef]

93. Hussain, M.; Liu, G.; Yousaf, B.; Ahmed, R.; Uzma, F.; Ali, M.U.; Ullah, H.; Butt, A.R. Regional and sectoral assessment on climate-Change in Pakistan: Social norms and indigenous perceptions on climate-Change adaptation and mitigation in relation to global context. J. Clean. Prod. 2018, 200, 791-808. [CrossRef]

94. Cobbinah, P.B.; Anane, G.K. Climate change adaptation in rural Ghana: Indigenous perceptions and strategies. Clim. Dev. 2016, 8, 169-178. [CrossRef]

95. Rehman, A.; Jingdong, L.; Chandio, A.A.; Hussain, I. Livestock production and population census in Pakistan: Determining their relationship with agricultural GDP using econometric analysis. Inf. Process. Agric. 2017, 4, 168-177. [CrossRef]

96. UNEP-DA. South Asia Environment Outlook 2009; United Nations Environment Program and Development Alternatives (UNEP-DA): New Delhi, India , 2009.

97. Mathew, R. Climate Change and Water Security in the Himalayan Region. Asia Policy 2013, 16, 39-44. [CrossRef]

98. Yang, Y.-C.E.; Brown, C.; Yu, W.; Wescoat, J.; Ringler, C. Water governance and adaptation to climate change in the Indus river basin. J. Hydrol. 2014, 519, 2527-2537. [CrossRef]

99. Grefalda, L.B.; Pulhin, J.M.; Tapia, M.A.; Anacio, D.B.; De Luna, C.C.; Sabino, L.L.; Garcia, J.E.; Peria, A.S.; Peras, R.J.J.; Gevaña, D.T.; et al. Building institutional resilience in the context of climate change in Aurora, Philippines. Environ. Res. 2020, 186, 109584. [CrossRef]

(C) 2020 by the authors. Licensee MDPI, Basel, Switzerland. This article is an open access article distributed under the terms and conditions of the Creative Commons Attribution (CC BY) license (http://creativecommons.org/licenses/by/4.0/). 